\title{
THE
}

\section{Reactive nitrogen and ozone over the western Pacific: Distribution, partitioning, and sources}

\author{
H. B. Singh \\ D. Herlth \\ R. Kolyer \\ L. Salas \\ J. D. Bradshaw
}

See next page for additional authors

Follow this and additional works at: https://digitalcommons.uri.edu/gsofacpubs

Terms of Use

All rights reserved under copyright.

\section{Citation/Publisher Attribution}

Singh, H. B., et al. (1996), Reactive nitrogen and ozone over the western Pacific: Distribution, partitioning, and sources, J. Geophys. Res., 101(D1), 1793-1808, doi: 10.1029/95JD01029.

Available at: https://doi.org/10.1029/95JD01029

This Article is brought to you for free and open access by the Graduate School of Oceanography at DigitalCommons@URI. It has been accepted for inclusion in Graduate School of Oceanography Faculty Publications by an authorized administrator of DigitalCommons@URI. For more information, please contact digitalcommons-group@uri.edu. 


\section{Authors}

H. B. Singh, D. Herlth, R. Kolyer, L. Salas, J. D. Bradshaw, S. T. Sandholm, D. D. Davis, J. Crawford, Y. Kondo,

R. Talbot, G. L. Gregory, G. W. Sachse, E. Brownell, D. R. Blake, F. S. Rowland, John Merrill, Brian G. Heikes,

S. C. Liu, P. J. Crutzen, and M. Kanakidou

This article is available at DigitalCommons@URI: https://digitalcommons.uri.edu/gsofacpubs/262 


\title{
Reactive nitrogen and ozone over the western Pacific: Distribution, partitioning, and sources
}

\author{
H. B. Singh, ${ }^{1}$ D. Herlth, ${ }^{1}$ R. Kolyer, ${ }^{1}$ L. Salas, ${ }^{2}$ J. D. Bradshaw, ${ }^{3}$ S. T. Sandholm, ${ }^{3}$ \\ D. D. Davis, ${ }^{3}$ J. Crawford ${ }^{3}$ Y. Kondo, ${ }^{4}$ M. Koike, ${ }^{4}$ R. Talbot, ${ }^{5}$ G. L. Gregory, ${ }^{6}$ \\ G. W. Sachse, ${ }^{6}$ E. Browell, ${ }^{6}$ D. R. Blake, ${ }^{7}$ F. S. Rowland, ${ }^{7}$ R. Newell, ${ }^{8}$ \\ J. Merrill, ${ }^{9}$ B. Heikes, ${ }^{9}$ S. C. Liu, ${ }^{10}$ P. J. Crutzen, ${ }^{11}$ M. Kanakidou ${ }^{12}$
}

\begin{abstract}
Measurements of important reactive nitrogen species (NO, $\mathrm{NO}_{2}, \mathrm{HNO}_{3}, \mathrm{PAN}$, PPN, $\left.\mathrm{NO}_{3}^{-}, \mathrm{NO}_{y}\right), \mathrm{C}_{1}$ to $\mathrm{C}_{6}$ hydrocarbons, $\mathrm{O}_{3}$, chemical tracers $\left(\mathrm{C}_{2} \mathrm{Cl}_{4}, \mathrm{CO}\right)$, and meteorological parameters were made in the troposphere $(0$ to $12 \mathrm{~km})$ over the western Pacific $\left(0^{\circ}-50^{\circ} \mathrm{N}\right)$ during the Pacific Exploratory Mission-West A campaign (SeptemberOctober 1991). Under clean conditions, mixing ratios of $\mathrm{NO}, \mathrm{NO}_{2}, \mathrm{NO}_{y}$, and $\mathrm{O}_{3}$ increased with altitude and showed a distinct latitudinal gradient. PAN showed a midtropospheric maximum, while nitric acid mixing ratios were generally highest near the surface. Measured $\mathrm{NO}_{y}$ concentrations were significantly greater than the sum of individually measured nitrogen species (mainly $\mathrm{NO}_{x}, \mathrm{PAN}$, and $\mathrm{HNO}_{3}$ ), suggesting that a large fraction of reactive nitrogen present in the atmosphere is made up of hitherto unknown species. This shortfall was larger in the tropics $(\approx 65 \%)$ compared to midlatitudes $(\approx 40 \%)$ and was minimal in air masses with high $\mathrm{HNO}_{3}$ mixing ratios ( $>100 \mathrm{ppt}$ ). A global threedimensional photochemical model has been used to compare observations with predictions and to assess the significance of major sources. It is possible that the tropical lightning source is much greater than commonly assumed, and both lightning source and its distribution remain a major area of uncertainty in the budgets of $\mathrm{NO}_{y}$ and $\mathrm{NO}_{x}$. $\mathrm{A}$ large disagreement between measurement and theory exists in the atmospheric distribution of $\mathrm{HNO}_{3}$. It appears that surface-based anthropogenic emissions provide nearly $65 \%$ of the global atmospheric $\mathrm{NO}_{y}$ reservoir. Relatively constant $\mathrm{NO}_{x} / \mathrm{NO}_{y}$ ratios imply that $\mathrm{NO}_{y}$ and $\mathrm{NO}_{x}$ are in chemical equilibrium and the $\mathrm{NO}_{y}$ reservoir may be an important in situ source of atmospheric $\mathrm{NO}_{x}$. Data are interpreted to suggest that only about $20 \%$ of the upper tropospheric $(7-12 \mathrm{~km}) \mathrm{NO}_{x}$ is directly attributable to its surface $\mathrm{NO}_{x}$ source, and free tropospheric sources are dominant. In situ release of $\mathrm{NO}_{x}$ from the $\mathrm{NO}_{y}$ reservoir, lightning, direct transport of surface $\mathrm{NO}_{x}$, aircraft emissions, and small stratospheric input collectively maintain the $\mathrm{NO}_{x}$ balance in the atmosphere. It is shown that atmospheric ratios of reactive nitrogen and sulfur species, along with trajectory analysis, can be used to pinpoint the source of Asian continental outflow. Compared to rural atmospheres over North America, air masses over the Pacific are highly efficient in net $\mathrm{O}_{3}$ production. Sources of tropospheric $\mathrm{NO}_{x}$ cannot yet be accurately defined due to shortcomings in measurements and theory.
\end{abstract}

\section{Introduction}

The NASA Global Tropospheric Experiment (GTE) consists of a series of field programs designed to elucidate the

\footnotetext{
${ }^{1}$ NASA Ames Research Center, Moffett Field, California. ${ }^{2}$ San Jose State University Foundation, Moffett Field, California.

${ }^{3}$ Georgia Institute of Technology, Atlanta.

${ }^{4}$ Nagoya University, Toyokawa, Japan.

${ }^{5}$ University of New Hampshire, Durham.

${ }^{6}$ NASA Langley Research Center, Hampton, Virginia.

${ }^{7}$ University of California, Irvine.

${ }^{8} \mathrm{MIT}$, Cambridge, Massachusetts.

${ }^{9}$ University of Rhode Island, Narragansett.

${ }^{10}$ NOAA Aeronomy Laboratory, Boulder, Colorado.

${ }^{11}$ Max Planck Institute for Chemistry, Mainz, Germany.

${ }^{12}$ Centre des Faibles Radioactivites, Laboratoire mixte CNRS/CEA, Gif-sur-Yvette, France.

Copyright 1996 by the American Geophysical Union.

Paper number 95JD01029.

0148-0227/96/95JD-01029\$05.00
}

composition and chemistry of the Earth's global atmosphere [McNeal et al., 1983]. The Pacific troposphere is a major region of the northern hemisphere that is relatively free of direct influences from man-made pollution. Significant industrial growth in Asia and North America in recent decades has the potential to greatly impact this pristine region. The western Pacific has the unique advantage of being alternately pristine or polluted during periods of easterly and westerly flows, respectively [Prospero and Savoie, 1989]. The period of early fall provides an opportunity to study pristine air over the Pacific as opposed to early spring when Asian continental outflow is at its peak. As part of GTE, a field experiment (Pacific Exploratory Mission (PEM)-West A) was performed in SeptemberOctober 1991 to principally study the budgets and chemistry of reactive nitrogen, ozone, and sulfur. A second follow-up mission which focused on the continental outflow was completed in the spring of 1994 (PEM-West B).

The PEM-West A had a strong airborne component (DC-8 aircraft) with several complementary surface sampling sites. Aircraft sampling centered on the western Pacific covering a 
Table 1. Grouping of PEM-West A Missions With Meteorological Trajectories and Air Mass Origin

\begin{tabular}{|c|c|c|c|c|}
\hline Mission & General Geographic Location & $\begin{array}{l}\text { Transport Wind Flow } \\
\text { (Trajectories) }\end{array}$ & Primary Air Mass & Air Mass Source Region \\
\hline 5,7 & $\begin{array}{l}\text { North and Northwest Pacific } \\
\text { (E and NE of Japan) }\end{array}$ & strong W-NW & continental polar air & North China/Siberia \\
\hline 6,8 & $\begin{array}{l}\text { into the subtropical high } \\
\left(30^{\circ} \mathrm{N}\right) \mathrm{SE} \text { of Japan }\end{array}$ & E-SE-S & maritime subtropical air & $\begin{array}{l}\text { subtropical high pressure } \\
\left(30^{\circ} \mathrm{N} 140^{\circ}-160^{\circ} \mathrm{E}\right)\end{array}$ \\
\hline 9 & $\begin{array}{l}\text { south of Japan, east of } \\
\text { Typhoon "Mireille" }\end{array}$ & S-SE & maritime tropical air & W/SW Pacific \\
\hline 10,11 & on west side of subtropical high & $\mathrm{SE}$ & maritime subtropical air & $\begin{array}{l}\text { subtropical high pressure } \\
\left(20^{\circ}-30^{\circ} \mathrm{N} 130^{\circ}-150^{\circ} \mathrm{E}\right)\end{array}$ \\
\hline 12 & Taiwan & $\begin{array}{l}\text { polar front about to pass } \\
\text { (NW-SE), east wind flow }\end{array}$ & maritime subtropical air & western tropical Pacific \\
\hline 13 & around Taiwan & $\begin{array}{l}\text { behind polar front in } \\
\text { W-NW wind flow }\end{array}$ & continental polar air & China Mainland \\
\hline $\begin{array}{l}14,15,16,17 \\
18\end{array}$ & $\begin{array}{l}\text { western Tropical Pacific } \\
\text { western/central tropical Pacific }\end{array}$ & $\begin{array}{l}\text { S-SE (tropical easterlies) } \\
\text { south of strong high- } \\
\text { pressure system }\end{array}$ & $\begin{array}{l}\text { maritime tropical air } \\
\text { maritime subtropical air }\end{array}$ & $\begin{array}{l}\text { equatorial Pacific } \\
\text { north central Pacific }\end{array}$ \\
\hline $\begin{array}{l}19,20 \\
21\end{array}$ & $\begin{array}{l}\text { tropical Pacific and Hawaii } \\
\text { from Hawaii to Moffett }\end{array}$ & $\begin{array}{l}\text { E-SE } \\
\text { from easterlies into } \\
\text { northwesterlies }\end{array}$ & $\begin{array}{l}\text { maritime subtropical air } \\
\text { maritime subtropical } \\
\text { air/marine polar air }\end{array}$ & $\begin{array}{l}\text { tropical/subtropical eastern Pacific } \\
\text { subtropical Pacific/Gulf of Alaska }\end{array}$ \\
\hline
\end{tabular}

latitude of $0^{\circ}-50^{\circ} \mathrm{N}$ and a longitude of $120^{\circ}-180^{\circ} \mathrm{E}$. Details about the experimental plan and the general study objectives are presented in the overview paper by Hoell et al. [this issue]. Aircraft measurements of important reactive nitrogen species $\left(\mathrm{NO}, \mathrm{NO}_{2}, \mathrm{HNO}_{3}, \mathrm{PAN}, \mathrm{PPN}, \mathrm{NO}_{3}^{-}, \mathrm{NO}_{y}\right.$ ), $\mathrm{O}_{3}, \mathrm{C}_{1}$ to $\mathrm{C}_{6}$ hydrocarbons, aerosols, chemical tracers $\left(\mathrm{C}_{2} \mathrm{Cl}_{4}, \mathrm{CO}\right)$, and meteorological parameters were made. $\left(\mathrm{NO}_{x}\right.$ is defined as $\mathrm{NO}+$ $\mathrm{NO}_{2} ; \mathrm{NO}_{y}$ is a measured quantity intended to measure the total of all reactive nitrogen (excluding ammonia and nitriles). PAN $\left(\mathrm{R}=\mathrm{CH}_{3}\right)$ and PPN $\left(\mathrm{R}=\mathrm{C}_{2} \mathrm{H}_{5}\right)$ are homologues of the series $\mathrm{RC}(\mathrm{O}) \mathrm{OONO}_{2} ; \mathrm{ppt}=10^{-12} \mathrm{vol} / \mathrm{vol} ; \mathrm{ppb}=10^{-9} \mathrm{vol} /$ vol.) In this manuscript we analyzed these data to quantitatively describe the distribution and partitioning of measured odd nitrogen and its relationship with ozone under polluted and pristine conditions. Model and experimental data are compared to show agreements and major shortcomings in our present knowledge of photochemical theory and sources of reactive nitrogen.

\section{Experiment, Meteorology, and Model}

PEM-West A utilized a DC-8 aircraft for all airborne measurements. A total of eighteen science and transit missions were conducted from September 16 to October 22, 1991. Missions 6-9, 12-13, and 15-17 were science flights from Japan, Hong Kong, and Guam, respectively. All other flights were transit flights. Missions 6-20 (latitude $0^{\circ}-42^{\circ} \mathrm{N}$ ), located west of Hawaii, were largely used for the analysis provided in this study. Trace chemicals specifically used in this study include nitrogen species, ozone, and hydrocarbons. Details of the measurement techniques have already been published and are summarized in the overview paper. Simply stated, PAN, PPN, and $\mathrm{C}_{2} \mathrm{Cl}_{4}$ were measured by electron capture-gas chromatography (EC-GC), ozone by ethylene chemiluminescence, nitric acid by mist chamber/IC technique [Talbot et al., 1990], and hydrocarbons by grab sampling and subsequent GC-FID analysis [Blake et al., this issue]. $\mathrm{NO}, \mathrm{NO}_{2}$, and $\mathrm{NO}_{y}$ were measured

Table 2. Mixing Ratios of Key Species Over Western Pacific During September-October 1990

\begin{tabular}{|c|c|c|c|c|c|c|c|c|c|c|}
\hline Latitude & $\mathrm{km}$ & $\begin{array}{c}\text { PAN, } \\
\text { ppt }\end{array}$ & $\begin{array}{c}\mathrm{HNO}_{3}, \\
\mathrm{ppt}\end{array}$ & $\begin{array}{c}\mathrm{NO}, \dagger \\
\mathrm{ppt}\end{array}$ & $\begin{array}{c}\mathrm{NO}_{2}, \\
\mathrm{ppt}\end{array}$ & $\begin{array}{c}\mathrm{NO}_{y}, \\
\mathrm{ppt}\end{array}$ & $\begin{array}{c}\text { Ozone, } \\
\mathrm{ppb}\end{array}$ & $\begin{array}{l}\mathrm{CO}, \\
\mathrm{ppb}\end{array}$ & $\begin{array}{c}\mathrm{C}_{2} \mathrm{H}_{2}, \\
\mathrm{ppt}\end{array}$ & $\begin{array}{c}\mathrm{C}_{2} \mathrm{Cl}_{4}, \\
\mathrm{ppt}\end{array}$ \\
\hline \multirow[t]{4}{*}{$25^{\circ}-42^{\circ} \mathrm{N}$} & $0-1$ & $\begin{array}{l}8.3 \pm \\
(2.0,4\end{array}$ & $\begin{array}{r}136.3 \pm \\
(68.0\end{array}$ & 8 & $\begin{array}{c}45.2 \\
30.2\end{array}$ & $\begin{array}{r}209.4= \\
(172 .\end{array}$ & 6 & $\begin{array}{r}81.5 \\
(84\end{array}$ & $\begin{array}{l}9.3 \\
3)\end{array}$ & \\
\hline & $0-3$ & $\begin{array}{r}15.0 \pm \\
(2.0,7\end{array}$ & $\begin{array}{c}119.6 \pm 137.5 \\
(74.0,22)\end{array}$ & $\begin{array}{l}6.0 \pm 6.7 \\
(3.6,31)\end{array}$ & $\begin{array}{c}44.9 \pm 42.4 \\
(34.1,93)\end{array}$ & $\begin{array}{c}248.9 \pm 139.9 \\
(189.0,100)\end{array}$ & $\begin{array}{l}24.8 \pm 14.6 \\
(20.8,124)\end{array}$ & $\begin{array}{l}83.4 \pm 14.7 \\
(83.7,123)\end{array}$ & $\begin{array}{r}105.1 \pm \\
(76.0,\end{array}$ & $\begin{array}{l}1.5 \\
76)\end{array}$ \\
\hline & $3-7$ & $\begin{array}{l}82.3 \pm 86.2 \\
(50.6,108)\end{array}$ & $\begin{array}{l}78.3 \pm 51.3 \\
(67.50,26)\end{array}$ & $\begin{array}{c}19.5 \pm 14.6 \\
(15.7,66)\end{array}$ & $\begin{array}{l}46.6 \pm 15.2 \\
(47.8,134)\end{array}$ & $\begin{array}{c}375.8 \pm 113.1 \\
(357.0,141)\end{array}$ & $\begin{array}{l}40.8 \pm 12.0 \\
(39.5,211)\end{array}$ & $\begin{array}{l}86.0 \pm 10.5 \\
(84.3,205)\end{array}$ & $\begin{array}{l}96.1 \pm 54.1 \\
(75.3,103)\end{array}$ & $\begin{array}{l}4.0 \pm 1.6 \\
(3.6,103)\end{array}$ \\
\hline & $7-13$ & $\begin{array}{l}78.0 \pm 44.0 \\
(78.1,105)\end{array}$ & $\begin{array}{c}34.9 \pm 14.1 \\
(31.0,12)\end{array}$ & $\begin{array}{l}58.3 \pm 62.5 \\
(40.7,110)\end{array}$ & $\begin{array}{l}65.3 \pm 24.5 \\
(63.9,123)\end{array}$ & $\begin{array}{c}527.5 \pm 129.0 \\
(536.0,124)\end{array}$ & $\begin{array}{l}50.8 \pm 15.0 \\
(51.0,172)\end{array}$ & $\begin{array}{l}90.5 \pm 10.5 \\
(91,0,158)\end{array}$ & $\begin{array}{c}115.9 \pm 42.3 \\
(121.3,74)\end{array}$ & $\begin{array}{l}3.7 \pm 0.8 \\
(3.6,103)\end{array}$ \\
\hline \multirow[t]{4}{*}{$0^{\circ}-25^{\circ} \mathrm{N}$} & 0 & & $\begin{array}{c}45.7 \pm 60.2 \\
(17.0,19)\end{array}$ & $\begin{array}{l}5.2 \pm 8.1 \\
(3.0,68)\end{array}$ & $\begin{array}{c}25.6 \pm 42.7 \\
(11.9,93)\end{array}$ & $\begin{array}{c}266.6 \pm 173.6 \\
(219.0,88)\end{array}$ & $\begin{array}{l}18.1 \pm 9.6 \\
(174 ., 140)\end{array}$ & $\begin{array}{l}78.8 \pm 11.5 \\
(74.3,135)\end{array}$ & & \\
\hline & $0-3$ & $\begin{array}{l}3.1 \pm 2.3 \\
(2.0,133)\end{array}$ & $\begin{array}{c}47.0 \pm 54.5 \\
(21.5,26)\end{array}$ & $\begin{array}{l}4.4 \pm 6.6 \\
(2.8,108)\end{array}$ & $\begin{array}{l}21.1 \pm 33.8 \\
(11.5,155)\end{array}$ & $\begin{array}{l}25.1 \pm 153.2 \\
(219.0,132)\end{array}$ & $\begin{array}{l}19.0 \pm 9.6 \\
(17.8,226)\end{array}$ & $\begin{array}{l}79.1 \pm 12.0 \\
(74.3,214)\end{array}$ & $\begin{array}{l}69.5 \pm 57.0 \\
(54.0,131)\end{array}$ & $\begin{array}{l}3.2 \pm 1.2 \\
(3.0,133)\end{array}$ \\
\hline & $3-7$ & $\begin{array}{l}24.1 \pm 30.3 \\
(16.0,177)\end{array}$ & $\begin{array}{c}35.9 \pm 26.7 \\
(26.0,30)\end{array}$ & $\begin{array}{l}9.1 \pm 6.2 \\
(7.5,127)\end{array}$ & $\begin{array}{l}19.4 \pm 9.8 \\
(16.2,214)\end{array}$ & $\begin{array}{c}282.9 \pm 127.7 \\
(263.0,180)\end{array}$ & $\begin{array}{l}31.4 \pm 11.8 \\
(27.8,315)\end{array}$ & $\begin{array}{l}86.2 \pm 11.2 \\
(84.3,315)\end{array}$ & $\begin{array}{l}69.5 \pm 34.0 \\
(66.2,186)\end{array}$ & $\begin{array}{l}3.0 \pm 1.0 \\
(2.9,149)\end{array}$ \\
\hline & $x$ & $\begin{array}{l}24.3 \pm 26.6 \\
(16.3,229)\end{array}$ & $\begin{array}{c}17.6 \pm 14.0 \\
(11.5,8)\end{array}$ & $\begin{array}{l}23.9 \pm 23.9 \\
(15.5,190)\end{array}$ & $\begin{array}{c}33.7 \pm 14.9 \\
(34.1,241)\end{array}$ & $\begin{array}{c}392.0 \pm 129.9 \\
(375.0,176)\end{array}$ & $\begin{array}{l}31.5 \pm 13.6 \\
(28.3,396)\end{array}$ & $\begin{array}{l}90.4 \pm 12.9 \\
(90.5,374)\end{array}$ & $\begin{array}{l}86.3 \pm 48.4 \\
(87.0,219)\end{array}$ & $\begin{array}{l}3.1 \pm 1.1 \\
(2.9,227)\end{array}$ \\
\hline
\end{tabular}

Data are from missions 6-20. Except for $\mathrm{HNO}_{3}, 180$-s merged data set is used. Cases with $\mathrm{CO}>110 \mathrm{ppb}$ and $\mathrm{NO}_{y}>800 \mathrm{ppt}$ are excluded.

* Mean $\pm 1 \sigma$ (median, number of data points).

$\dagger$ NO data are for zenith angle of less than $60^{\circ}$. 

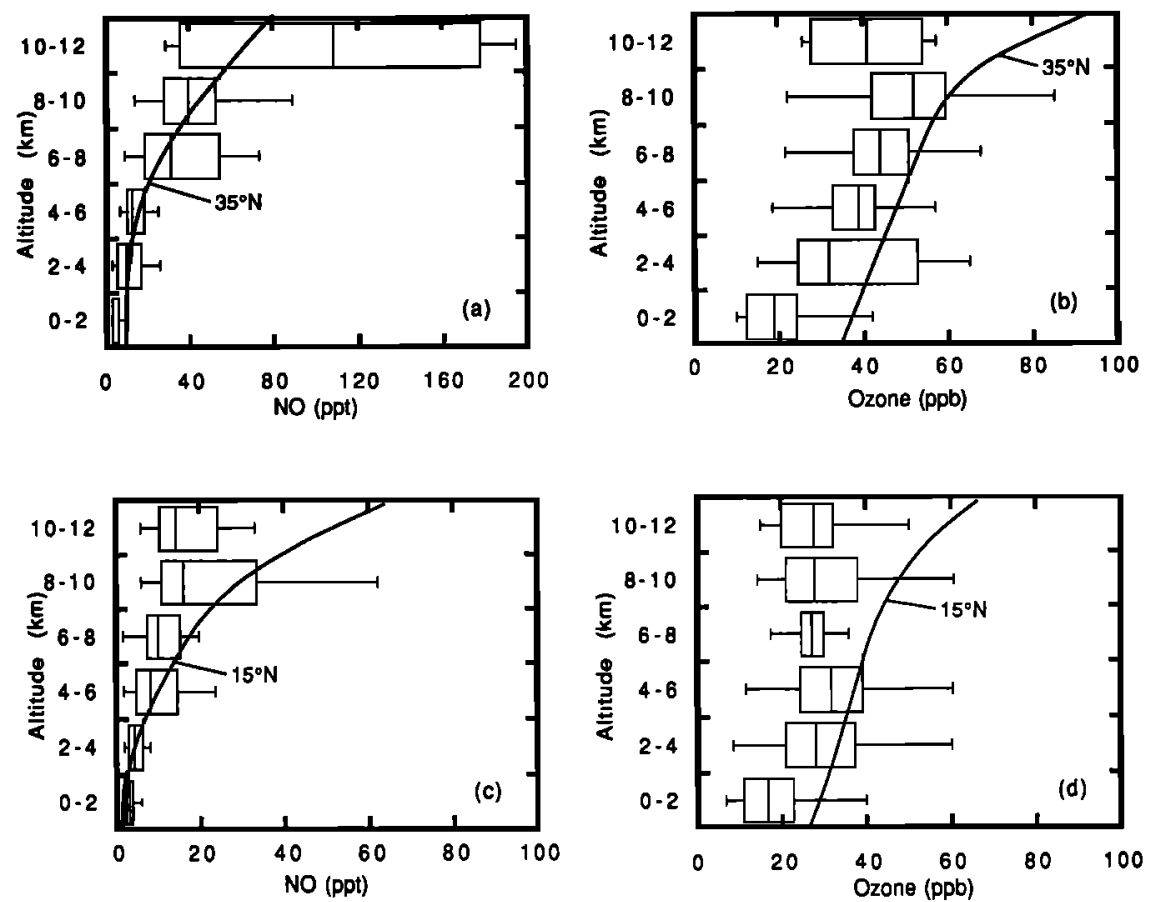

Figure 1. Vertical distribution of $\mathrm{NO}$ and $\mathrm{O}_{3}$ over the $(\mathrm{a}, \mathrm{b})$ subtropical/midlatitude and (c, d) tropical/ equatorial western Pacific. Data from missions 6-20 are divided in two latitude bands of $25^{\circ}-42^{\circ} \mathrm{N}$ (midlatitude/subtropical) and $0^{\circ}-25^{\circ} \mathrm{N}$ (tropical/equatorial) and are further filtered (CO $<110 \mathrm{ppb}$ and $\mathrm{NO}_{y}<800$ $\mathrm{ppt}$ ) to remove fresh sources of pollution. Data are binned in $2-\mathrm{km}$ altitude bands. Line within the box shows median value, box boundaries indicate quartiles, and the lines extending from the box represent maximum and minimum within the accepted data (see text). Solid lines show the results of simulation with a threedimensional global photochemical model for the period of September at $35^{\circ} \mathrm{N}$ and $15^{\circ} \mathrm{N}$ latitudes and $145^{\circ} \mathrm{E}$ longitude. Unless otherwise stated, the Georgia Institute of Technology $\mathrm{NO}_{y}$ data have been used.
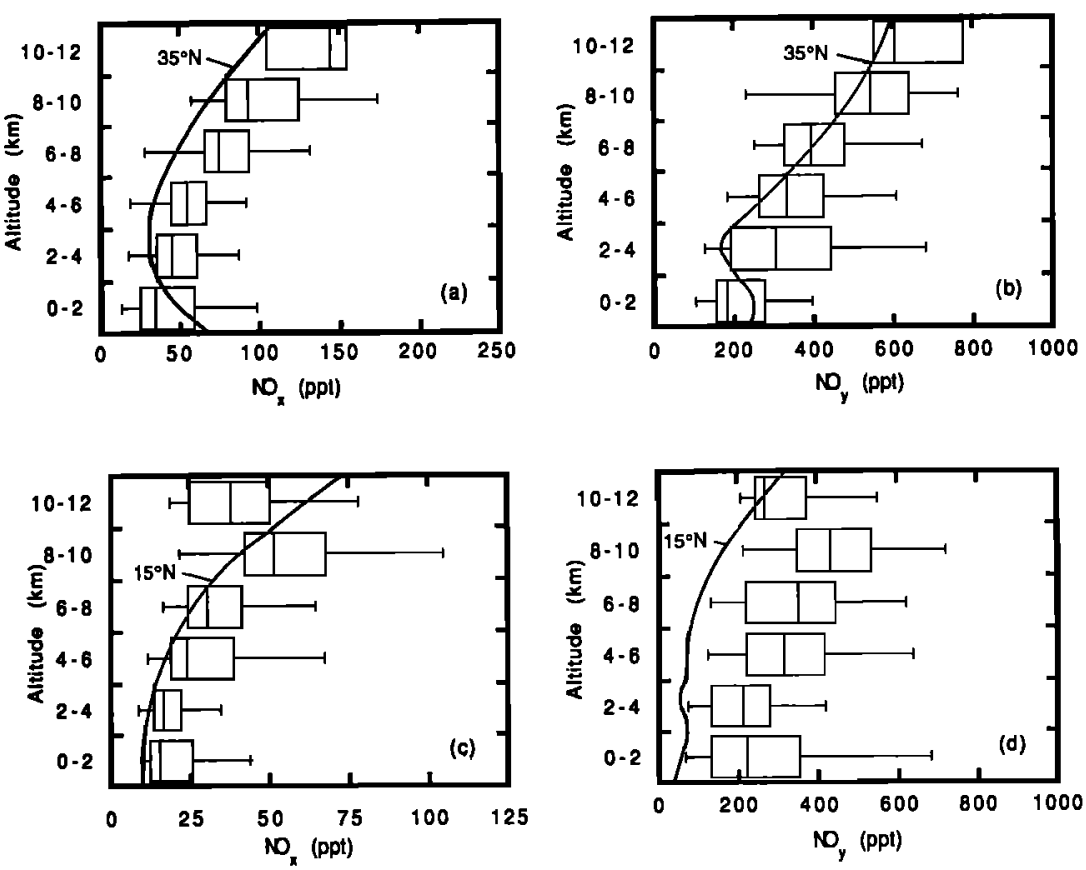

Figure 2. Vertical distribution of $\mathrm{NO}_{x}$ and $\mathrm{NO}_{y}$ over the $(\mathrm{a}, \mathrm{b})$ midlatitude/subtropical and (c, d) tropical/ equatorial western Pacific. Data and model as described in Figure 1. 

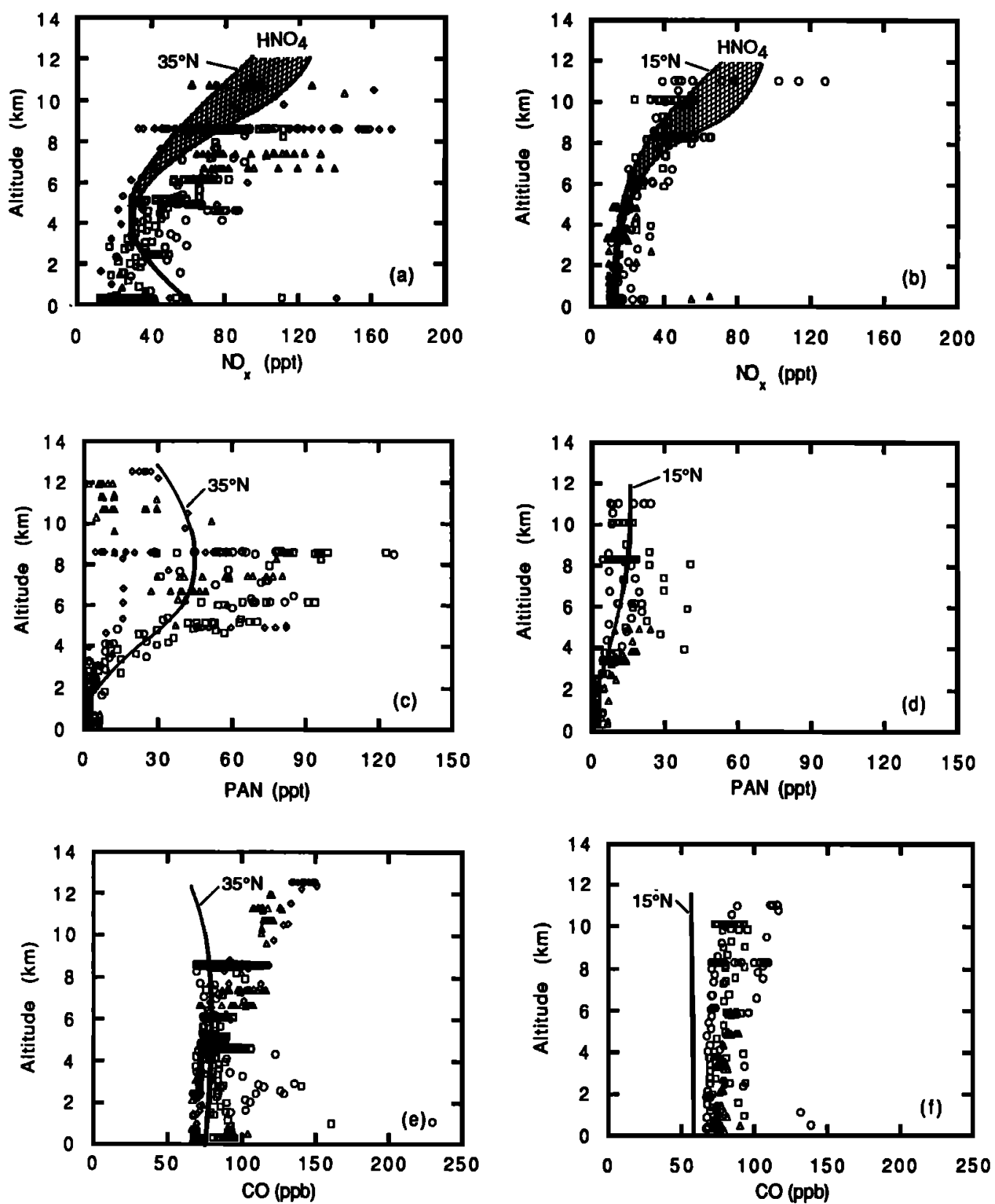

Figure 3. Vertical distribution of $\mathrm{NO}_{x}, \mathrm{PAN}$, and $\mathrm{CO}$ over subtropical/midlatitude and tropical/equatorial western Pacific. The midlatitude/subtropical set represents data from missions 6 (circle), 8 (square), 9 (triangle), and 10 (diamond) which had favorable meteorology and least continental impact. Missions 15 (circle), 18 (square), and 20 (diamond) are similarly chosen to represent clean tropical/equatorial background. Model output as in Figure 1. The dashed area in Figures 3a and 3b shows model-calculated abundance of $\mathrm{HO}_{2} \mathrm{NO}_{2}$

by a laser-induced fluorescence (LIF) instrument developed by Georgia Institute of Technology (GIT) [Sandholm et al., 1994]. $\mathrm{NO}$ and $\mathrm{NO}_{y}$ were also measured by Nagoya University (NU) investigators using the chemiluminescent technique [Kondo et al., this issue]. A map of the geographical extent covered during the PEM-West A missions and a summary table of individual flights as well as instrumentation used are provided in the overview papers by Hoell et al. [this issue].

While NO measurements showed excellent agreement, substantial differences in $\mathrm{NO}_{y}$ measurements between the two techniques were observed. Water interference was found to be a major source of uncertainity in the NU instrument causing the data below $3 \mathrm{~km}$ to be largely unreliable. However, this was not the only reason for the disagreement as measurements at altitudes above $7 \mathrm{~km}$, where water interference should have been negligible, also disagreed. Here the GIT NO $y$ measurements were typically higher than those reported by NU by about a factor of 2 with most pronounced differences in tropical air masses. A panel of experts, after careful evaluation of these data sets, concluded that the $\mathrm{NO}_{y}$ data collected by GIT using the LIF technique suffered from fewer problems and provided a preferred data set [Crosley, 1993]. Based on the panel recommendation, we have used the GIT $\mathrm{NO}_{y}$ data set in this study unless otherwise stated. We caution that in some 
Table 3. Median Mixing Ratios of Select Reactive Nitrogen Species From Subarctic and Pacific Studies

\begin{tabular}{|c|c|c|c|c|c|c|c|c|c|}
\hline \multirow[b]{2}{*}{ Location } & \multirow[b]{2}{*}{ Date } & \multicolumn{2}{|c|}{$\mathrm{NO}_{x}, \mathrm{ppt}$} & \multicolumn{2}{|c|}{ PAN, ppt } & \multicolumn{2}{|c|}{$\mathrm{HNO}_{3}$, ppt } & \multicolumn{2}{|c|}{$\mathrm{NO}_{y}, \mathrm{ppt}$} \\
\hline & & $0-3 \mathrm{~km}$ & $3-6 \mathrm{~km}$ & $0-3 \mathrm{~km}$ & $3-6 \mathrm{~km}$ & $0-3 \mathrm{~km}$ & $3-6 \mathrm{~km}$ & $0-3 \mathrm{~km}$ & $3-6 \mathrm{~km}$ \\
\hline Marine eastern Pacific, $35^{\circ}-45^{\circ} \mathrm{N}$ & Aug./Sept. 1986 & 20 & 30 & 10 & 120 & 80 & 120 & 101 & 298 \\
\hline Central Pacific Hawaii, $19^{\circ} \mathrm{N}^{*}$ & May/June 1988 & & 31 & & 16 & & 92 & & 253 \\
\hline Alaska, $50^{\circ}-70^{\circ} \mathrm{N}$ & July/Aug. 1989 & 19 & 31 & 17 & 234 & 50 & 45 & 284 & 639 \\
\hline Hudson Bay, Canada, $45^{\circ}-55^{\circ} \mathrm{N}$ & July/Aug. 1990 & 41 & 43 & 50 & 317 & 81 & 51 & 251 & 735 \\
\hline Labrador, Canada, $50^{\circ}-60^{\circ} \mathrm{N}$ & July/Aug. 1990 & 33 & 45 & 61 & 298 & 69 & 45 & 202 & 394 \\
\hline Western Pacific, $25^{\circ}-45^{\circ} \mathrm{N}$ & Sept./Oct. 1991 & 37 & 59 & 2 & 50 & 74 & 67 & 189 & 357 \\
\hline Western Pacific $\left(0^{\circ}-25^{\circ} \mathrm{N}\right)$ & Sept./Oct. 1991 & 15 & 23 & 2 & 16 & 21 & 26 & 219 & 263 \\
\hline
\end{tabular}

*Data were collected at a fixed site (Mauna Loa) $3.4 \mathrm{~km}$ above sea level and are selected for downslope conditions.

companion papers the $\mathrm{NU} \mathrm{NO}_{y}$ data have been exclusively presented and analyzed [Kondo et al., this issue; Koike et al., this issue]. It is also noted that measured $\mathrm{NO}_{2}$ levels were, on the average, larger than those calculated from NO assuming photostationary state conditions [Crawford et al., this issue]. One possible interpretation of this disagreement may be that the measured $\mathrm{NO}_{2}$ (and $\mathrm{NO}_{x}$ ) is too high due to possible interferences from unknown $\mathrm{NO}_{y}$ species. A possible candidate at high altitudes would be $\mathrm{HO}_{2} \mathrm{NO}_{2}$ which may dissociate in contact with surfaces within the instrument. In this study we assume that the measured $\mathrm{NO}_{2}$ data as reported are correct to within their stated accuracy [Sandholm et al., 1994].

The meteorological description for the region and for each of the missions are described by Bachmeier et al. [this issue]. Extensive trajectory analysis and 5- to 10-day back trajectories were available from Merrill [this issue]. Typically, 10-15 trajectories were calculated for each flight starting at altitudes that extended from 1 to $12 \mathrm{~km}$. The analysis of data presented in this paper took advantage of the overall synoptic meteorology and trajectory information in selecting missions of interest. Table 1 provides a basic summary of the meteorology that prevailed during each of the PEM-West A missions.

The data collected over the western Pacific were compared with the output of a three-dimensional global photochemical model (MOGUNTIA). This three-dimensional model contained a detailed chemical scheme describing $\mathrm{O}_{3} / \mathrm{NO}_{x} / \mathrm{CO} /$ $\mathrm{CH}_{4} / \mathrm{C}_{2} \mathrm{H}_{6} / \mathrm{C}_{3} \mathrm{H}_{8}$ chemistry with more than 100 photochemical reactions, as described by Kanakidou et al. [1991]. The model used a global emission inventory with a $10^{\circ}$ latitude $\times 10^{\circ}$ longitude resolution and contained 10 vertical levels from surface to $100 \mathrm{hPa}$. Rainout of key species (e.g., $\mathrm{HNO}_{3}, \mathrm{H}_{2} \mathrm{O}_{2}$, and $\mathrm{CH}_{3} \mathrm{COOH}$ ) was based on climatological rainfall rates and scavenging efficiencies described by Langner and Rodhe [1991] for in-cloud scavenging of particles and gases. The $\mathrm{OH}$ distri-
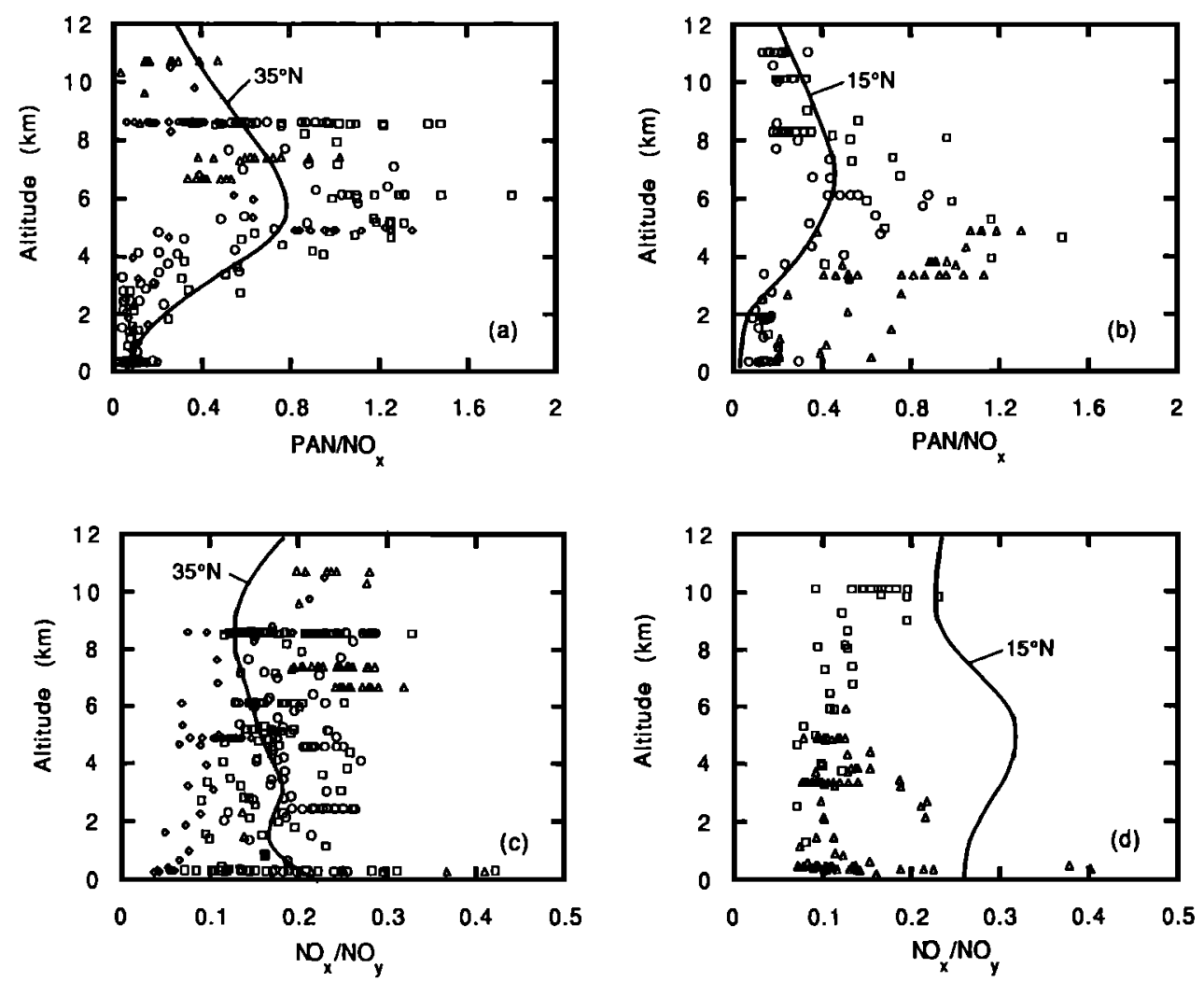

Figure 4. Vertical distribution of $\mathrm{PAN} / \mathrm{NO}_{x}$ and $\mathrm{NO}_{x} / \mathrm{NO}_{y}$ over the $(\mathrm{a}, \mathrm{c})$ midlatitude/subtropical and $(\mathrm{b}, \mathrm{d})$ tropical/equatorial western Pacific, as in Figure 3. 

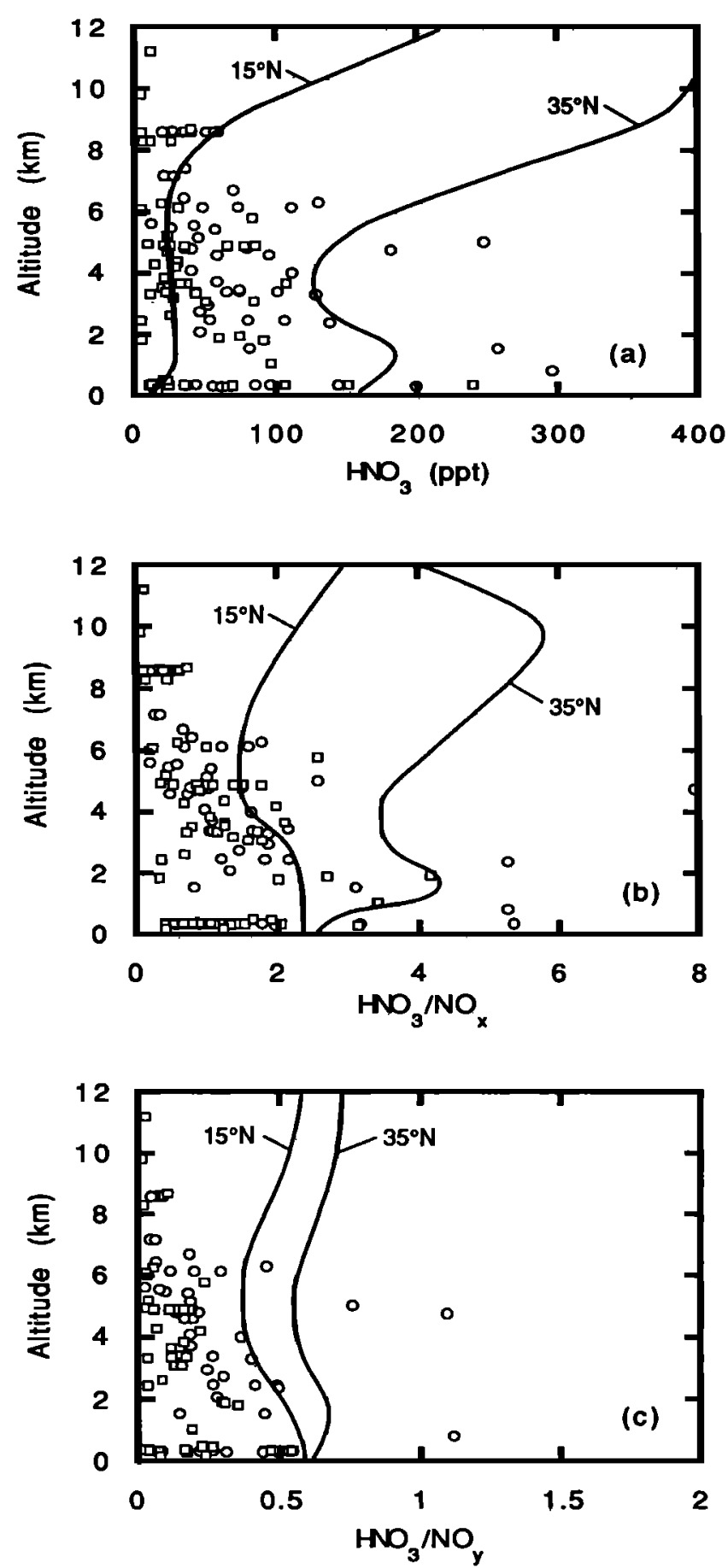

Figure 5. Vertical distribution of $\mathrm{HNO}_{3}, \mathrm{HNO}_{3} / \mathrm{NO}_{x}$, and $\mathrm{HNO}_{3} / \mathrm{NO}_{y}$ over the western Pacific. Circles represent data from $25^{\circ}$ to $42^{\circ} \mathrm{N}$ and squares represent data from $0^{\circ}$ to $25^{\circ} \mathrm{N}$. Lines show model results.

bution in this model is fitted to a methyl chloroform lifetime of 5.5 years. The basic model has been described by Crutzen and Zimmerman [1991] and Kanakidou et al. [1992]. Heterogeneous reactions involving $\mathrm{N}_{2} \mathrm{O}_{5}$ and $\mathrm{NO}_{3}$ reactions on aerosols and in-cloud $\mathrm{N}_{2} \mathrm{O}_{5}$ conversion to $\mathrm{HNO}_{3}$ are also included [Dentener and Crutzen, 1993]. $\mathrm{NO}_{x}$ emissions totaling $38 \mathrm{Tg}$ $(\mathrm{N}) / \mathrm{yr}(20 \mathrm{Tg}(\mathrm{N}) / \mathrm{yr}$ from fossil fuel sources, $8 \mathrm{Tg}(\mathrm{N}) / \mathrm{yr}$ from lightning, $6 \mathrm{Tg}(\mathrm{N}) / \mathrm{yr}$ from biomass burning, and $4 \mathrm{Tg}(\mathrm{N}) / \mathrm{yr}$ from soils) are distributed as described by Crutzen and Zimmer- man [1991]. The spatial and temporal stochastic distribution of convection events has been used for the emission distribution of $\mathrm{NO}_{x}$ by lightning. Aircraft emissions of $\mathrm{NO}_{x}(0.7 \pm 0.4 \mathrm{Tg}(\mathrm{N}) / \mathrm{yr})$ were not specifically included in this model in part because it was felt that the uncertainties associated with the lightning source are probably much larger than this source. The convective transport parameterization published by Feichter and Crutzen [1990] has been extended to the upper layer of the model $(100 \mathrm{hPa})$. Injection of $\mathrm{O}_{3}$ from the stratosphere was $480 \mathrm{Tg} / \mathrm{yr}$ $\left(4 \times 10^{10}\right.$ molecules $\left.\mathrm{cm}^{2} \mathrm{~s}^{-1}\right)$. The mixing ratios of select nitrogen species such as $\mathrm{HNO}_{3}$ and $\mathrm{NO}_{x}$ were fixed at the upper boundary of the model and correspond to a stratospheric source of about $0.5 \mathrm{Tg}(\mathrm{N}) / \mathrm{yr}\left(67 \% \mathrm{HNO}_{3}, 33 \% \mathrm{NO}_{x}\right)$. In addition, total global sources were $\mathrm{CH}_{4}, 544 \mathrm{Tg} / \mathrm{yr} ; \mathrm{CO}, 1550$ $\mathrm{Tg} / \mathrm{yr} ; \mathrm{C}_{2} \mathrm{H}_{6}, 14 \mathrm{Tg} / \mathrm{yr}$; and $\mathrm{C}_{3} \mathrm{H}_{8}, 17 \mathrm{Tg} / \mathrm{yr}$. Although results from this model were available on a global basis, model output for the month of September at $145^{\circ} \mathrm{E}$ longitude and the prescribed latitude (western Pacific) is used to compare with PEM-West A measurements. Sensitivity studies were also performed to assess the impact of sources such as lightning.

\section{Results and Discussion}

As stated earlier, a comprehensive set of reactive nitrogen measurements ( $\mathrm{NO}, \mathrm{NO}_{2}, \mathrm{HNO}_{3}, \mathrm{PAN}, \mathrm{PPN}, \mathrm{NO}_{3}^{-}$, and $\mathrm{NO}_{y}$ ) were made during the PEM-West A deployment. Different sampling periods were employed in these measurements. Several merged sets containing matching data averaged within the $\mathrm{PAN}, \mathrm{HNO}_{3}$, and $\mathrm{NO}_{y}$ sampling windows were created for the purposes of data analysis. For $\mathrm{NO}, \mathrm{NO}_{2}$, and $\mathrm{NO}_{y}$, and $\mathrm{O}_{3}$, 180 -s time windows were used. The $\mathrm{HNO}_{3}$ sampling window was the longest and data merged to this window was used in all cases involving $\mathrm{HNO}_{3}$. Data were further segregated into midlatitude/subtropical $\left(42^{\circ}-25^{\circ} \mathrm{N}\right)$ and tropical/equatorial $\left(25^{\circ}-\right.$ $0^{\circ} \mathrm{N}$ ) latitude bands. To eliminate short-term local influences (e.g., ship plumes) and fresh pollution episodes, numerical filters $\left(\mathrm{CO}<110 \mathrm{ppb}\right.$ and $\left.\mathrm{NO}_{y}<800 \mathrm{ppt}\right)$ were also used where appropriate. Based on synoptic meteorology, missions 6 , 8,9 , and 10 were combined to give a view of the midlatitude/ subtropical $\left(\approx 35^{\circ} \mathrm{N}\right)$ distributions while missions 15,18 , and 20 are used to describe the tropical/equatorial latitude region $\left(\approx 12^{\circ} \mathrm{N}\right)$. Back trajectories showed that during previous five or so days, these air masses were only minimally impacted by fresh continental emissions. Missions 7 and 13 were used to show outflow conditions impacting the western Pacific from primarily Asian sources. Budget and partitioning of reactive nitrogen were assessed based entirely on the $\mathrm{HNO}_{3}$ matched data set.

\section{Atmospheric Distributions Over the Western Pacific: Mixing Ratios, Variabilities, and Vertical Structures}

In this section we look at the distribution key reactive nitrogen (NO, $\mathrm{NO}_{x}, \mathrm{PAN}_{1} \mathrm{HNO}_{3}$, and $\mathrm{NO}_{y}$ ) measured during this experiment. Table 2 provides concentrations of $\mathrm{O}_{3}$, key reactive nitrogen, and tracer $\left(\mathrm{C}_{2} \mathrm{Cl}_{4}, \mathrm{CO}, \mathrm{C}_{2} \mathrm{H}_{2}\right)$ species as a function of altitude for two select latitude bands. NO data are restricted to zenith angle of less than $60^{\circ}$. Box plots of the vertical distribution of $\mathrm{NO}, \mathrm{O}_{3}$ (Figure 1), and $\mathrm{NO}_{x}, \mathrm{NO}_{y}$ (Figure 2) at midlatitude/subtropical and tropical/equatorial latitudes are shown. Standard statistical techniques were used to prepare these box plots. Line within the box shows median value, box boundaries indicate lower and upper quartiles, and the lines extending from the box represent maximum and min- 

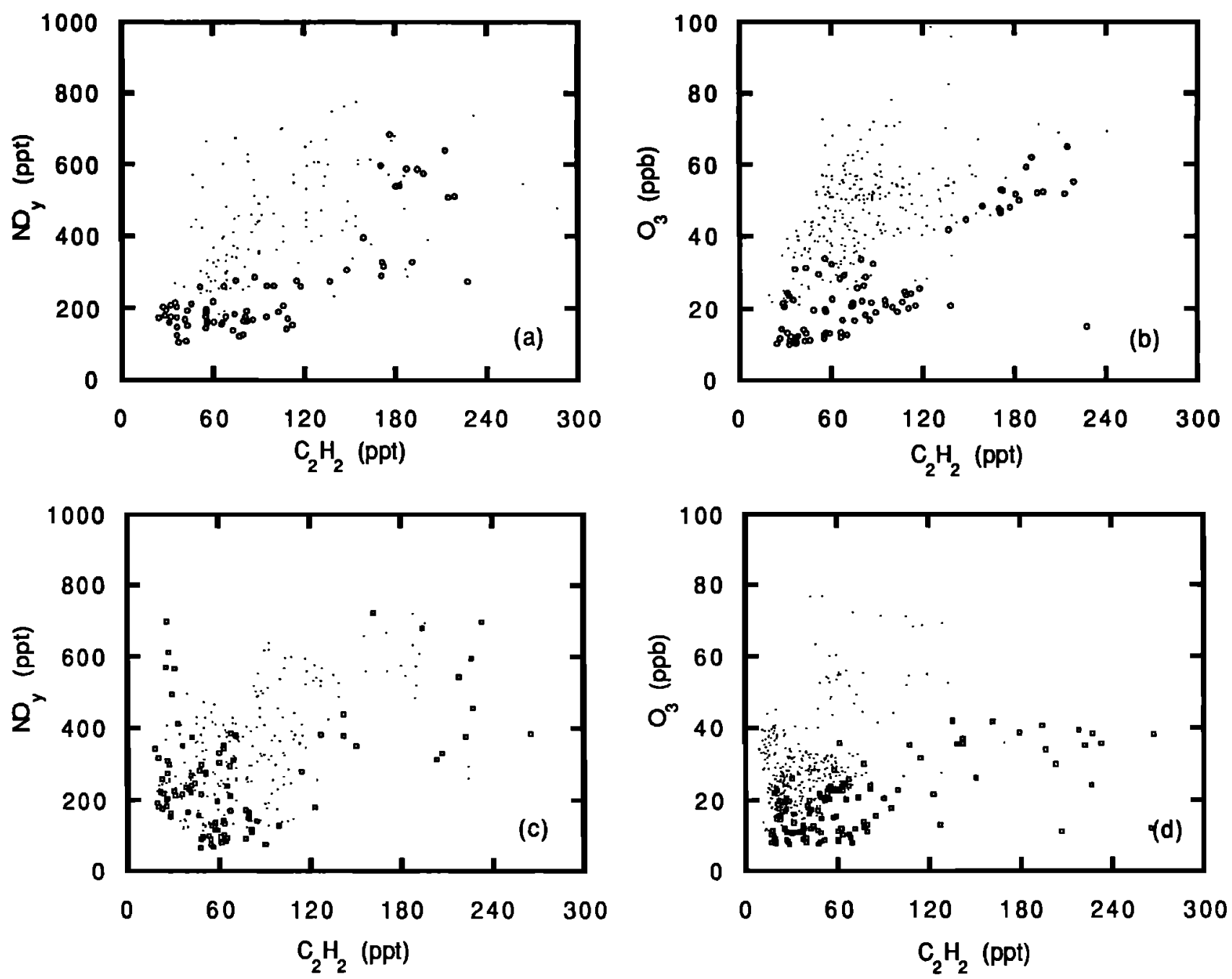

Figure 6. Correlation of $\mathrm{NO}_{y}$ and $\mathrm{O}_{3}$ mixing ratios with those of $\mathrm{C}_{2} \mathrm{H}_{2}$ over the (a, b) midlatitude/ subtropical and (c, d) tropical/equatorial western Pacific. Data as described in Figure I. Open symbols represent surface $(0-3 \mathrm{~km})$ and dots represent the free troposphere $(3-12 \mathrm{~km})$.

imum values that fall within the statistically acceptable range which is defined as data bounded by robust lower (lower quartile $-1.5 \times$ interquartile distance) and upper (upper quartile + $1.5 \times$ interquartile distance) limit. Outlying data points excluded by this procedure $(0-10 \%$ of data) are not shown in Figures 1 and 2 . Solid line shows the results of simulation by the MOGUNTIA model at $35^{\circ} \mathrm{N}$ and $15^{\circ} \mathrm{N}$ latitudes and $145^{\circ} \mathrm{E}$ longitude. One of the key inputs to ozone formation is the amount of NO available [Davis et al., this issue]. Extremely low NO concentrations were observed in the boundary layer at all latitudes with a median of about $4 \mathrm{ppt}$ (Table 2). NO concentrations predicted by the model are somewhat larger than those observed, resulting in a slight overprediction of the mean ozone content. Perhaps the largest discrepancy between measurements and model output is in the $\mathrm{NO}_{y}$ levels at tropical latitudes (Figure 2d). A possible reason for this may be that the tropical lightning source may be larger than that used in the model. Additionally, as we shall see later, this is also a region where there is a great discrepancy between measured $\mathrm{NO}_{y}$ and its accounting by known species.

Figure 3 shows the distribution of $\mathrm{NO}_{x}, \mathrm{PAN}$, and $\mathrm{CO}$ for select midlatitude/subtropical missions (missions 6, 8, 9, and
10) and tropical/equatorial latitude missions (missions 15, 16, and 20). While the measured and modeled $\mathrm{NO}_{\lambda}$ values, in general, appear in agreement, there are important differences. At midlatitudes (Figure 3a), measured $\mathrm{NO}_{x}$ values are below those predicted near the surface and are higher aloft. The higher $\mathrm{NO}_{x}$ values predicted within the first $2 \mathrm{~km}$ are directly related to the higher $\mathrm{NO}$ predicted. It is possible that pernitric acid $\left(\mathrm{HO}_{2} \mathrm{NO}_{2}\right)$, when present, may be converted in instruments via surface-catalyzed processes and measured as $\mathrm{NO}_{2}$. Model-predicted values of $\mathrm{HO}_{2} \mathrm{NO}_{2}$ are also shown in shaded areas (Figures $3 \mathrm{a}, 3 \mathrm{~b}$ ). Addition of the $\mathrm{HO}_{2} \mathrm{NO}_{2}$ mixing ratios to calculated $\mathrm{NO}_{x}$ does improve the agreement above $7 \mathrm{~km}$. Figure $3 \mathrm{c}$ shows the vertical distribution of PAN for midlatitude air with a clear indication of a maximum between $6-8 \mathrm{~km}$ in reasonable agreement with that predicted by the model. This PAN midtropospheric maximum is a likely result of both convective outflow at the 6- to $8-\mathrm{km}$ altitudes and a balance between its formation and destruction rates which are strong functions of altitude. Such a maximum was less evident at subtropical latitudes because of the extremely low mixing ratios (10-15 ppt). It is noted that the free-tropospheric PAN abundance over the western Pacific under clean conditions is 

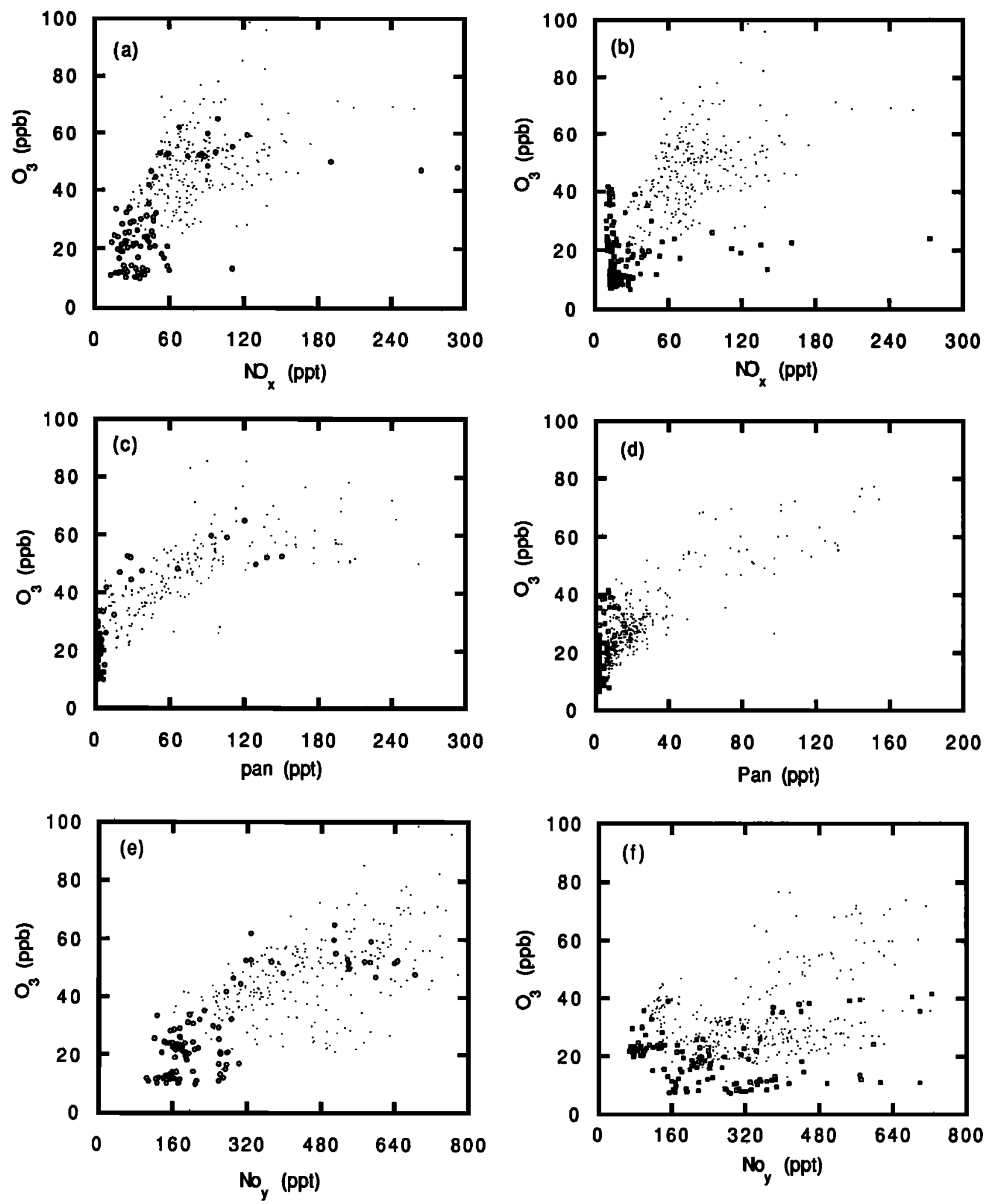

Figure 7. Correlation of $\mathrm{O}_{3}$ mixing ratios with those of $\mathrm{NO}_{x}, \mathrm{PAN}$, and $\mathrm{NO}_{y}$ over the (a, c, e) midlatitude/ subtropical and (b, d, f) tropical/equatorial western Pacific. Same as in Figure 6.

substantially lower than that measured over the eastern Pacific and in the arctic/subarctic environments. Data collected over the eastern Pacific were close to the North American continent and perhaps more impacted by pollution sources. Median mixing ratios of key reactive nitrogen species from many of these studies have been summarized in Table 3 [Atlas et al., 1992; Carroll et al., 1990; Huebert et al., 1990; Sandholm et al., 1992, 1994; Singh et al., 1990, 1992, 1994]. Also shown in Figure 3e and $3 \mathrm{f}$ are measured and modeled $\mathrm{CO}$ concentrations. This and many other models [e.g., Liu et al., this issue], in general, 

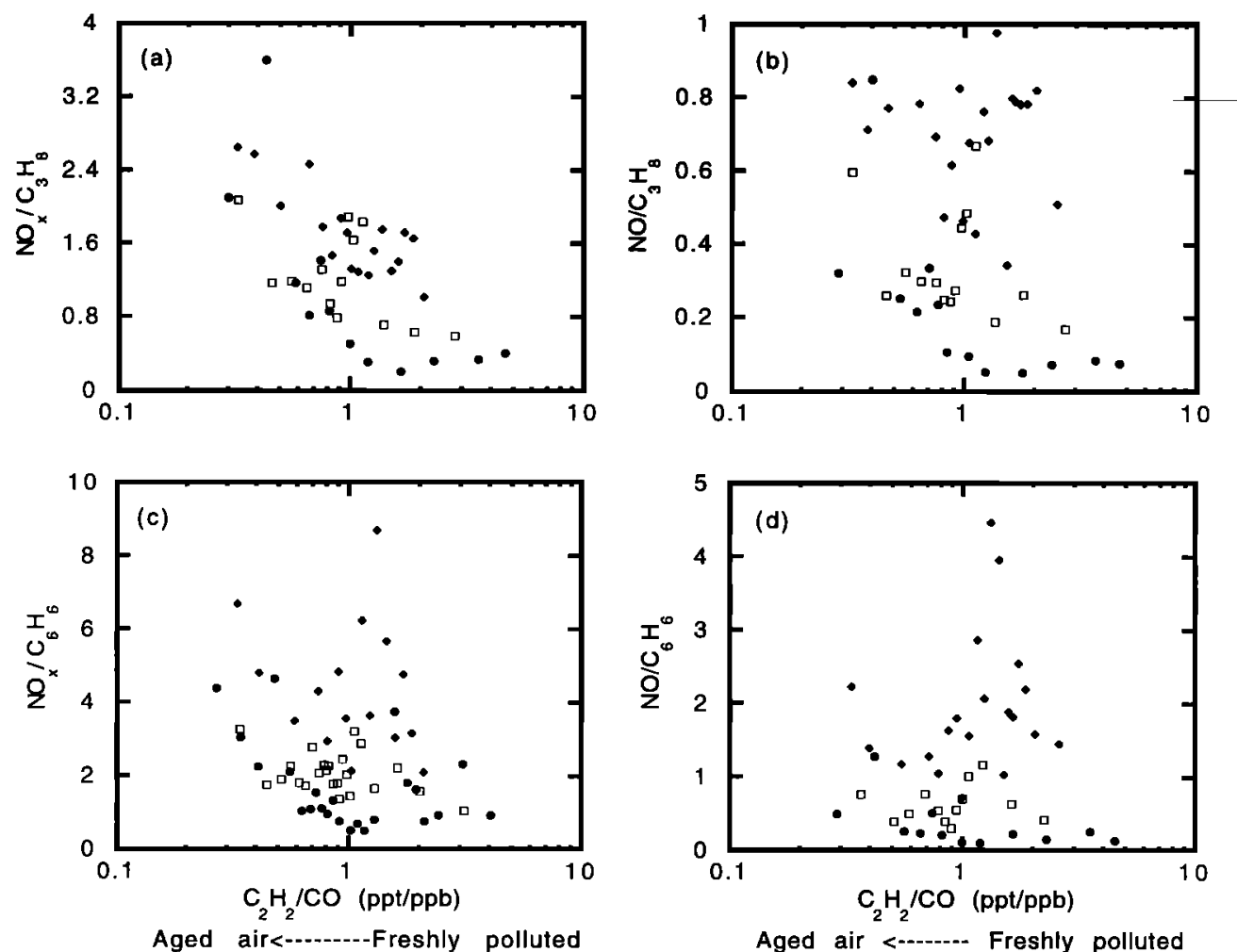

Figure 8. $\mathrm{NO}_{x} /$ hydrocarbon and NO/hydrocarbon ratios as a function of air mass age and altitude; $0-3 \mathrm{~km}$ (circle); $3-7 \mathrm{~km}$ (square), 7-12 km (diamond). Each symbol is an average of 10 data points. Hydrocarbons selected are propane $\left(\mathrm{C}_{3} \mathrm{H}_{8}\right)$ and benzene $\left(\mathrm{C}_{6} \mathrm{H}_{6}\right)$.

are unable to correctly simulate the increasing concentrations of long-lived tracers ( $\mathrm{CO}$ and hydrocarbons) with altitude, possibly due to inadequate treatment of convective processes.

Figure 4 shows the ratios of $\mathrm{PAN} / \mathrm{NO}_{x}$ and $\mathrm{NO}_{x} / \mathrm{NO}_{y}$ at the two selected latitude bands. Although there is substantial scatter in the data, the general profile of the $\mathrm{PAN} / \mathrm{NO}_{x}$ ratio is predicted by this model with a maximum that is near $6-$ to $8-\mathrm{km}$ altitudes. This $\mathrm{PAN} / \mathrm{NO}_{x}$ ratio measured over the western $\mathrm{Pa}$ cific is significantly lower than observed at previous midlatitude or arctic/subarctic experiments (Table 3). Over the eastern Pacific, PAN/NO $\mathrm{Natios}_{x}$ at about $5-\mathrm{km}$ altitudes were $4-5$ and extremely high ratios (5-10) were measured at the arctic/ subarctic regions [Ridley et al., 1990; Singh et al., 1992]. The $\mathrm{NO}_{x} / \mathrm{NO}_{y}$ ratio over the midlatitude western Pacific (Figure

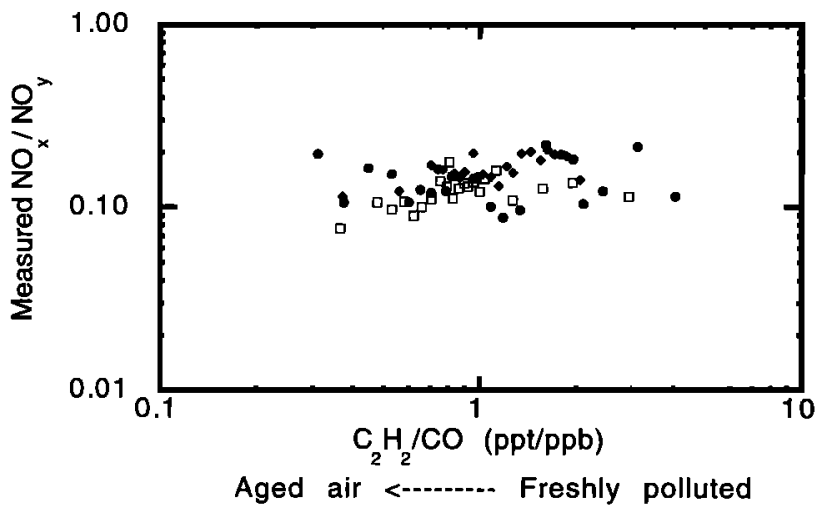

Figure 9. $\mathrm{NO}_{x} / \mathrm{NO}_{y}$ ratio as a function of air mass age and altitude. Same as in Figure 8.
$4 c$ ) is in reasonable accord with the model and with the observed median values of 0.1-0.2 over the eastern Pacific [Carroll et al., 1990]. The $\mathrm{NO}_{x} / \mathrm{NO}_{y}$ measured ratio deviates from the model at tropical/equatorial latitudes (Figure 4d) largely due to the underprediction of $\mathrm{NO}_{y}$ mixing ratios (Figure $2 \mathrm{~d}$ ). In general, the abundance and vertical structures of $\mathrm{NO}_{x}$ and PAN over the western Pacific do not deviate greatly from predictions. This is not true of $\mathrm{NO}_{y}$ mixing ratios, especially at tropical latitudes.

Measurements describing the distribution of $\mathrm{HNO}_{3}, \mathrm{HNO}_{3}$ / $\mathrm{NO}_{x}$, and $\mathrm{HNO}_{3} / \mathrm{NO}_{y}$ at the two selected latitude bands are shown in Figure 5. The measured $\mathrm{HNO}_{3}$ mixing ratios are, in general, lower than those predicted, especially at midlatitude, and the differences are greatest at higher altitudes. The synthesis of $\mathrm{HNO}_{3}$ largely occurs from reaction between $\mathrm{NO}_{2}$ and $\mathrm{OH}$ (during the day) and $\mathrm{N}_{2} \mathrm{O}_{5}$ heterogeneous conversion (at night). The model-predicted $\mathrm{HNO}_{3} / \mathrm{NO}_{x}$ ratio of 3-5 is much larger than that calculated from measurements during PEMWest A but in reasonable agreement with that found at Mauna Loa and over the eastern Pacific [Huebert et al., 1990; Norton et al., 1992; Atlas et al., 1992]. Below $6 \mathrm{~km}$ the predicted $\mathrm{HNO}_{3} /$ $\mathrm{NO}_{x}$ is in better agreement with the tropical data. Similarly, $\mathrm{HNO}_{3} / \mathrm{NO}_{y}$ measured ratio is much lower than predicted.

The possibility cannot be ruled out that there may be problems with both $\mathrm{HNO}_{3}$ measurements and/or with the simulation of the removal processes and chemistry of $\mathrm{HNO}_{3}$. Since $\mathrm{NO}_{x}$ is a major precursor of $\mathrm{HNO}_{3}$ and the rate of formation is relatively fast (a few days), a direct relationship between $\mathrm{NO}_{x}$ and $\mathrm{HNO}_{3}$ mixing ratios is reasonable to expect [e.g., Norton et al., 1992]. It was found that in the boundary layer $(0-3 \mathrm{~km}), \mathrm{NO}_{x}$ and $\mathrm{HNO}_{3}$ were correlated $(R=0.77)$ and 
Table 4. Reactive Nitrogen Budget and Distribution As a Function of Latitude and Altitude Over Western Pacific

\begin{tabular}{|c|c|c|c|c|c|c|c|}
\hline Latitude & $\begin{array}{c}\text { Altitude, } \\
\text { km }\end{array}$ & $\mathrm{PAN} / \mathrm{NO}_{y}$ & $\mathrm{NO}_{x} / \mathrm{NO}_{y}$ & $\mathrm{HNO}_{3} / \mathrm{NO}_{y}$ & $\mathrm{NO}_{3}^{-} / \mathrm{NO}_{y}$ & $\mathrm{NO}_{y} / \mathrm{NO}_{y}$ & $\begin{array}{c}\mathrm{NO}_{y}-\mathrm{NO}_{y}, \\
\mathrm{ppt}\end{array}$ \\
\hline \multirow[t]{5}{*}{$25^{\circ}-42^{\circ} \mathrm{N}$} & $0-1^{*}$ & $\begin{array}{c}0.02 \pm 0.02 \\
(0.02,9) \ddagger\end{array}$ & $\begin{array}{c}0.20 \pm 0.07 \\
(0.17,10)\end{array}$ & $\begin{array}{c}0.42 \pm 0.29 \\
(0.37,10)\end{array}$ & $\begin{array}{c}0.11 \pm 0.05 \\
(0.10,6)\end{array}$ & $\begin{array}{c}0.63 \pm 0.33 \\
(0.50,9)\end{array}$ & $\begin{array}{c}64.5 \pm 62.4 \\
(88.8,9)\end{array}$ \\
\hline & $0-3^{*}$ & $\begin{array}{c}0.05 \pm 0.07 \\
(0.02,19)\end{array}$ & $\begin{array}{c}0.19 \pm 0.06 \\
(0.18,20)\end{array}$ & $\begin{array}{c}0.38 \pm 0.22 \\
(0.31,19)\end{array}$ & $\begin{array}{c}0.11 \pm 0.08 \\
(0.09,9)\end{array}$ & $\begin{array}{c}0.62 \pm 0.24 \\
(0.57,18)\end{array}$ & $\begin{array}{c}84.7 \pm 65.5 \\
(89.6,18)\end{array}$ \\
\hline & $3-7^{*}$ & $\begin{array}{c}0.20 \pm 0.16 \\
(0.16,25)\end{array}$ & $\begin{array}{c}0.18 \pm 0.07 \\
(0.17,27)\end{array}$ & $\begin{array}{c}0.25 \pm 0.23 \\
(0.18,26)\end{array}$ & $\begin{array}{c}0.13 \pm 0.10 \\
(0.16,8)\end{array}$ & $\begin{array}{c}0.63 \pm 0.27 \\
(0.56,24)\end{array}$ & $\begin{array}{c}142.0 \pm 111.0 \\
(143.2,24)\end{array}$ \\
\hline & $7-12^{*}$ & $\begin{array}{c}0.17 \pm 0.06 \\
(0.17,16)\end{array}$ & $\begin{array}{c}0.21 \pm 0.05 \\
(0.20,16)\end{array}$ & $\begin{array}{c}0.07 \pm 0.02 \\
(0.06,11)\end{array}$ & $\begin{array}{c}0.02 \pm 0.02 \\
(0.02,5)\end{array}$ & $\begin{array}{c}0.41 \pm 0.07 \\
(0.41,11)\end{array}$ & $\begin{array}{r}305.5 \pm 67.7 \\
(308.9,11)\end{array}$ \\
\hline & $7-12 \dagger$ & $\begin{array}{c}0.26 \pm 0.07 \\
(0.26,17)\end{array}$ & $\begin{array}{c}0.35 \pm 0.14 \\
(0.33,16)\end{array}$ & $\begin{array}{c}0.12 \pm 0.06 \\
(0.10,12)\end{array}$ & $\begin{array}{c}0.04 \pm 0.04 \\
(0.01,5)\end{array}$ & $\begin{array}{c}0.71 \pm 0.18 \\
(0.57,11)\end{array}$ & $\begin{array}{c}106.0 \pm 77.7 \\
(93.7,11)\end{array}$ \\
\hline \multirow[t]{5}{*}{$0^{\circ}-25^{\circ} \mathrm{N}$} & $0-1 *$ & $\begin{array}{c}0.01 \pm 0.01 \\
(0.01,18)\end{array}$ & $\begin{array}{c}0.16 \pm 0.11 \\
(0.14,19)\end{array}$ & $\begin{array}{c}0.20 \pm 01.7 \\
(0.17,15)\end{array}$ & $\begin{array}{c}0.15 \pm 0.13 \\
(0.14,18)\end{array}$ & $\begin{array}{c}0.33 \pm 0.26 \\
(0.28,13)\end{array}$ & $\begin{array}{c}216.9 \pm 179.6 \\
(260.6,13)\end{array}$ \\
\hline & $0-3^{*}$ & $\begin{array}{c}0.02 \pm 0.02 \\
(0.01,27)\end{array}$ & $\begin{array}{c}0.14 \pm 0.10 \\
(0.12,29)\end{array}$ & $\begin{array}{c}0.20 \pm 0.16 \\
(0.17,21)\end{array}$ & $\begin{array}{c}0.13 \pm 0.12 \\
(0.13,21)\end{array}$ & $\begin{array}{c}0.32 \pm 0.22 \\
(0.27,18)\end{array}$ & $\begin{array}{c}212.0 \pm 160.4 \\
(190.7,18)\end{array}$ \\
\hline & $3-7^{*}$ & $\begin{array}{c}0.09 \pm 0.07 \\
(0.09,34)\end{array}$ & $\begin{array}{c}0.10 \pm 0.03 \\
(0.10,35)\end{array}$ & $\begin{array}{c}0.11 \pm 0.06 \\
(0.12,24)\end{array}$ & $\begin{array}{c}0.10 \pm 0.06 \\
(0.08,11)\end{array}$ & $\begin{array}{c}0.31 \pm 0.11 \\
(0.29,23)\end{array}$ & $\begin{array}{c}214.2 \pm 100.0 \\
(218.9,23)\end{array}$ \\
\hline & $7-12^{*}$ & $\begin{array}{c}0.06 \pm 0.04 \\
(0.04,22)\end{array}$ & $\begin{array}{c}0.15 \pm 0.04 \\
(0.15,21)\end{array}$ & $\begin{array}{c}0.05 \pm 0.04 \\
(0.03,5)\end{array}$ & $\begin{array}{c}0.05 \pm 0.05 \\
(0.04,13)\end{array}$ & $\begin{array}{c}0.32 \pm 0.06 \\
(0.30,5)\end{array}$ & $\begin{array}{c}302.6 \pm 37.3 \\
(293.2,5)\end{array}$ \\
\hline & $7-12 \dagger$ & $\begin{array}{c}0.15 \pm 0.07 \\
(0.13,37)\end{array}$ & $\begin{array}{c}0.38 \pm 0.13 \\
(0.35,31)\end{array}$ & $\begin{array}{c}0.10 \pm 0.09 \\
(0.04,8)\end{array}$ & $\begin{array}{c}0.20 \pm 0.25 \\
(0.10,17)\end{array}$ & $\begin{array}{c}0.60 \pm 0.11 \\
(0.64,8)\end{array}$ & $\begin{array}{c}80.9 \pm 40.7 \\
(62.0,8)\end{array}$ \\
\hline
\end{tabular}

${ }^{*}$ Georgia Institute of Technology (GIT) $\mathrm{NO}_{y}$ data. Data are for missions 6-20 and are filtered for $\mathrm{CO}<110 \mathrm{ppb}$ and $\mathrm{NO}_{y}<800 \mathrm{ppt}$. $\dagger$ Nagoya University $\mathrm{NO}_{y}$ data valid for only $7-12 \mathrm{~km}$.

$\ddagger$ Mean $\pm 1 \sigma$ (median, number of data points). $\mathrm{NO}_{y i}=\mathrm{NO}_{x}+\mathrm{PAN}+\mathrm{PPN}+\mathrm{HNO}_{3}$.

higher $\mathrm{HNO}_{3}$ levels, in general, coexisted with higher $\mathrm{NO}_{x}$ levels. However, this was not found to be the case in the middle (3-7 km) and the upper troposphere (7-12 km) where $\mathrm{HNO}_{3}$ mixing ratios were largely independent of the $\mathrm{NO}_{x}$ present. Collectively, the lack of correlation with $\mathrm{NO}_{x}$ and other tracers, disagreement with theory, and an extremely low $\mathrm{HNO}_{3}$ / $\mathrm{NO}_{x}$ ratio may a hint at some $\mathrm{HNO}_{3}$ measurement problem. However, special tests designed to verify the validity of this technique have uncovered no identifiable instrumental problems (R. Talbot, University of New Hampshire, private communication, 1994). There are also persuasive arguments to suggest that severe shortcomings in the simulation of $\mathrm{HNO}_{3}$ transport and chemistry currently exist. The removal processes involving rainout and washout are often localized and sporadic and difficult to simulate accurately in a climatological model. It is also possible that there are unknown processes (surface catalyzed?) that rapidly convert $\mathrm{HNO}_{3}$ to $\mathrm{NO}_{x}$ and these are neither well known nor simulated in current models. Based on very limited information [Travagli, 1938], it has been speculated that nitric acid could react with formaldehyde on concentrated sulfuric acid aerosols to form intermediate organic species (such as $\mathrm{HOCH}_{2} \mathrm{ONO}_{2}, \mathrm{CH}_{2}\left(\mathrm{ONO}_{2}\right)_{2}$ ) which may provide both a reservoir of reactive nitrogen and a possible in situ source of $\mathrm{NO}_{x}$ [Chatfield, 1994; Fan et al., 1994]. Such proposals need to be further studied under controlled experimental conditions.

\section{Relationships Between Reactive Nitrogen, Ozone, and Tracer Species: Sources of Tropospheric $\mathrm{NO}_{x}$ and $\mathrm{NO}_{y}$}

The relationships among reactive nitrogen, ozone, and select tracer species were explored to see if these could shed any light on the nature of their sources. Hydrocarbons (e.g., $\mathrm{C}_{2} \mathrm{H}_{2}$ ) and halocarbons (e.g., $\mathrm{C}_{2} \mathrm{Cl}_{4}$ ) are generally considered good tracers of anthropogenic activity. Figure 6 shows the relationship of $\mathrm{NO}_{y}$ and $\mathrm{O}_{3}$ with $\mathrm{C}_{2} \mathrm{H}_{2}$ for boundary layer and freetropospheric conditions. It is evident from Figure 6 that in general, high $\mathrm{NO}_{y}$ and $\mathrm{O}_{3}$ values, both in the boundary layer and aloft, are associated with correspondingly high values of $\mathrm{C}_{2} \mathrm{H}_{2}$, suggesting an impact from continental combustion sources. There were occasional instances when high $\mathrm{NO}_{y}$ levels coexisted with extremely low $\mathrm{C}_{2} \mathrm{H}_{2}$ mixing ratios, but these were nearly exclusively associated with shipboard plumes in the boundary layer and the influences of the stratosphere at high altitudes. We must, however, emphasize that such direct correlations cannot be used to establish a conclusive cause and effect. There are strong latitudinal gradients in the mean distributions of a number of tracer species largely as a result of greater sources at northern midlatitudes and greater sinks in the tropics. Dynamical processes thus can be responsible for some of observed correlations which may be related only indirectly to the impact of sources. For very high $\mathrm{C}_{2} \mathrm{H}_{2}$ concentrations (>100 ppt) however, a direct impact is reasonably inferred. In general, correlations of $\mathrm{NO}_{y}$ and $\mathrm{O}_{3}$ with a variety of tracers indicated the substantial impact of continental sources at all altitudes.

Figure 7 shows the relationship between $\mathrm{O}_{3}$ and its direct $\left(\mathrm{NO}_{x}\right)$ and possible indirect precursors (PAN and $\mathrm{NO}_{y}$ ). In the middle/subtropic latitudes there is a direct correlation between the mixing ratios of $\mathrm{O}_{3}$ and those of $\mathrm{NO}_{x}, \mathrm{PAN}$, and $\mathrm{NO}_{y}$. The $\mathrm{NO}_{y}-\mathrm{O}_{3}$ correlations are comparable to previous studies but are not so strong as observed in the stratosphere [Sandholm et al., 1992; Murphy et al., 1993; Singh et al., 1994]. The situation in tropical/equatorial latitude is more difficult to comprehend. Here $\mathrm{O}_{3}$ appeared uncorrelated with $\mathrm{NO}_{y}$ except at very high altitudes when $\mathrm{NO}_{y}$ exceeded $400 \mathrm{ppt}$ and stratospheric influences were present. The boundary layer data were probably impacted by ship emissions but even in the free troposphere the correlation is extremely weak. This lack of correlation in the subtropics makes sense only if $\mathrm{NO}_{y}$ here is largely composed of oxidized species such as $\mathrm{HNO}_{3}$ and organic nitrates even though very low $\mathrm{HNO}_{3}$ levels were actually observed. Also in this region there is a net photochemical sink of $\mathrm{O}_{3}$ [Davis et al., this issue], causing such a correlation to 
break down. These tracer and reactive nitrogen relationships are consistent with the photochemical control of ozone by reactive nitrogen species and the impact of continental emissions on the latter. Correlations with other anthropogenic tracers (e.g., $\mathrm{C}_{2} \mathrm{Cl}_{4}$ ) and surface-based tracers (e.g., ${ }^{210} \mathrm{~Pb}$ ) are in concert with the view that surface emissions are relatively rapidly lofted into the free troposphere and spread globally [Dibb et al., this issue]. As stated earlier, in virtually all cases the distribution of tracer species is sufficiently complex that the mean reservoir of reactive nitrogen cannot be neatly partitioned into source categories.

Figure 8 shows a plot of the $\mathrm{NO}_{x} / \mathrm{HC}$ ratio as a function of air mass age, indicated by the $\mathrm{C}_{2} \mathrm{H}_{2} / \mathrm{CO}$ ratio, with data segregated by altitude. The $\mathrm{C}_{2} \mathrm{H}_{2} / \mathrm{CO}$ ratio is a measure of the relative processing (age!) of the air mass since its last contact with fresh sources. High values suggest relatively recent contact with fresh sources and low values are indicative of an aged air mass, as discussed in greater detail by Smyth et al. [this issue]. Propane $\left(\mathrm{C}_{3} \mathrm{H}_{8}\right)$ and benzene $\left(\mathrm{C}_{6} \mathrm{H}_{6}\right)$ are selected because these have distinct surface sources (combustion and natural gas emissions) and well-defined lifetimes (3 weeks for $\mathrm{C}_{3} \mathrm{H}_{8}$ and 2 weeks for $\mathrm{C}_{6} \mathrm{H}_{6}$ ) that are significantly longer than the $\mathrm{NO}_{x}$ lifetime which can be calculated to be about $0.5-2$ days in the lower troposphere increasing to about 5-7 days in the upper troposphere [Ehhalt et al., 1992; Singh and Zimmerman, 1992]. All known sources of these hydrocarbons occur
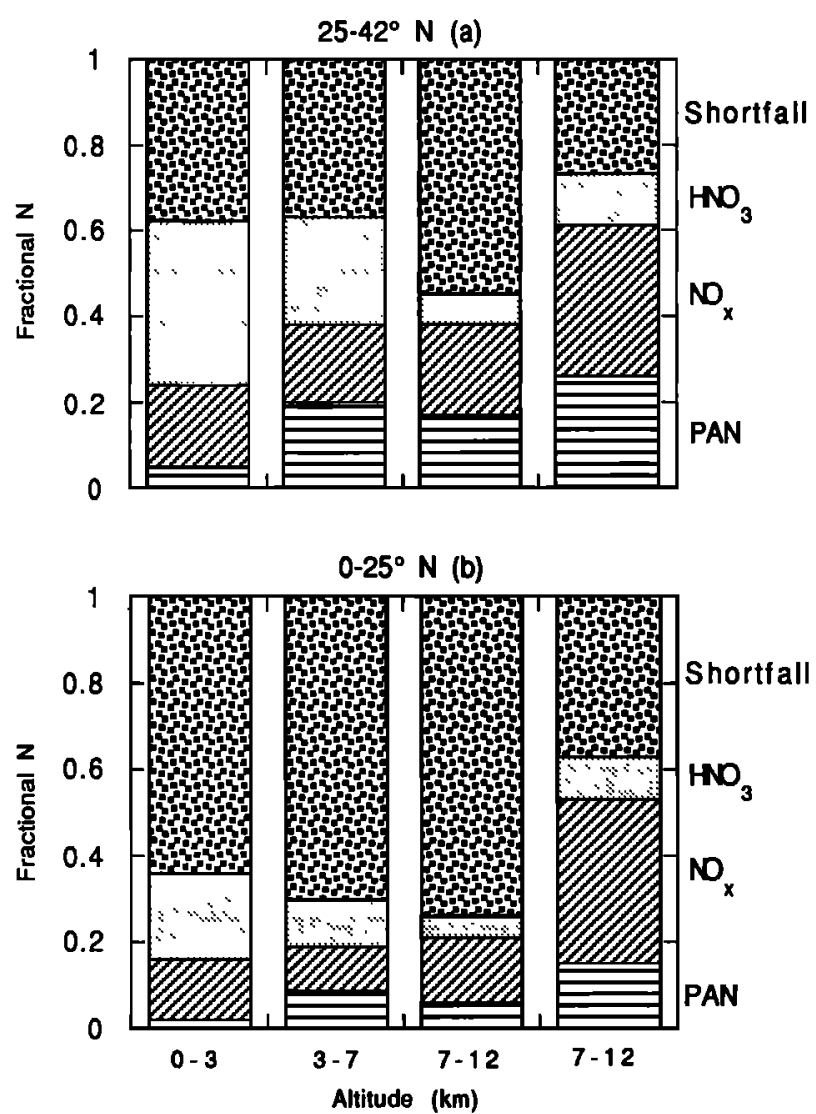

Figure 10. Reactive nitrogen budget for the (a) midlatitude/ subtropical and (b) tropical/equatorial western Pacific. $Y$ axis (from bottom to top) shows $\mathrm{PAN} / \mathrm{NO}_{y}, \mathrm{NO}_{x} / \mathrm{NO}_{y}, \mathrm{HNO}_{3} /$ $\mathrm{NO}_{y}$, and the fractional shortfall. The $7-$ to $12-\mathrm{km}$ bin is repeated to show the difference when the Nagoya University $\mathrm{NO}_{y}$ data are used.
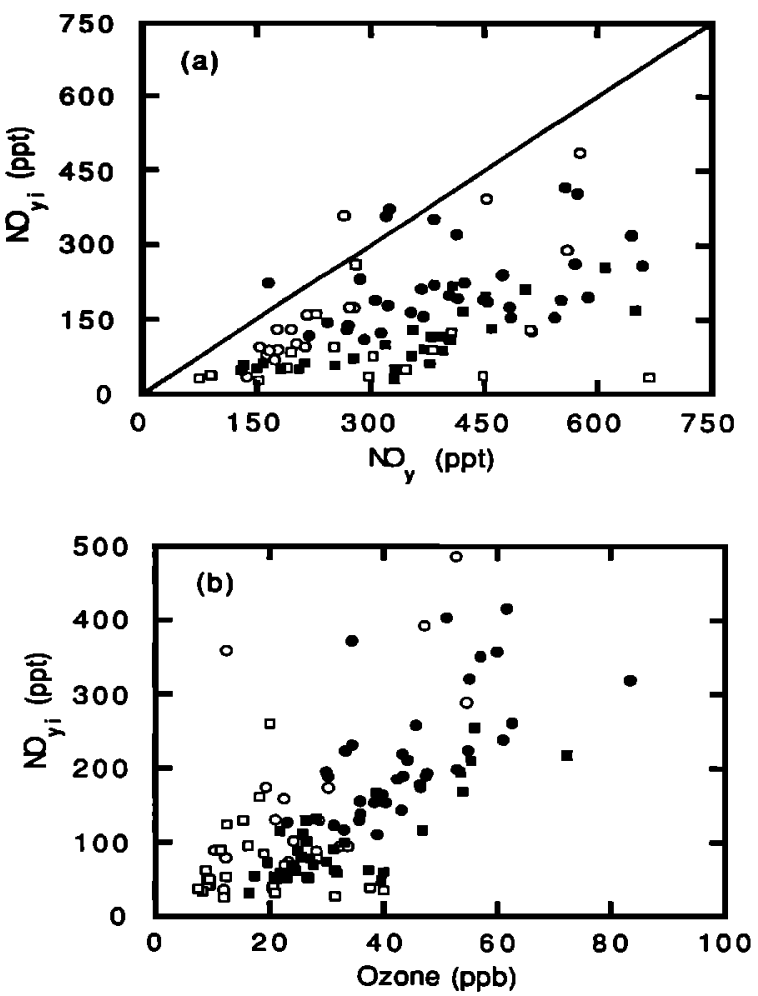

Figure 11. Relationship of $\mathrm{NO}_{y z}$ mixing ratios with those of $\mathrm{NO}_{y}$ and $\mathrm{O}_{3}$ over the western Pacific. Circles and squares represent data from $25^{\circ}-42^{\circ} \mathrm{N}$ and $0^{\circ}-25^{\circ} \mathrm{N}$, respectively. Open symbols represent surface $(0-3 \mathrm{~km})$ data, while solid symbols represent the free troposphere $(3-12 \mathrm{~km}) . \mathrm{NO}_{y^{\prime}}$ is defined as the sum of $\mathrm{NO}+\mathrm{NO}_{2}+\mathrm{PAN}+\mathrm{PPN}+\mathrm{HNO}_{3}$.

near the Earth's surface. The dominant combustion sources of $\mathrm{NO}_{x}$ (fossil fuel, $20 \mathrm{Tg}(\mathrm{N}) / \mathrm{yr}$; biomass burning, $6 \mathrm{Tg}(\mathrm{N}) / \mathrm{yr}$ ) also originate near the Earth's surface and hydrocarbons and $\mathrm{NO}_{x}$ are generally coemitted. In general, the $\mathrm{NO}_{x} / \mathrm{HC}$ ratio should be at its highest near-surface source regions and decline with time because of the shorter lifetime of $\mathrm{NO}_{x}$. Figure 8 shows that exactly opposite is the case and both the $\mathrm{NO}_{x} / \mathrm{HC}$ and the $\mathrm{NO} / \mathrm{HC}$ ratios are the largest for the most aged air masses and at higher altitudes. This is only possible if large amounts of atmospheric $\mathrm{NO}_{x}$ is coming from nonsurface (free tropospheric) sources. $\mathrm{NO}_{x} / \mathrm{HC}$ ratio for relatively fresh air masses (say, $\mathrm{C}_{2} \mathrm{H}_{2}$ (ppt)/CO $(\mathrm{ppb}) \approx 2$ ) is some $4-5$ times larger at $7-12 \mathrm{~km}$ than at $0-3 \mathrm{~km}$. Figure 8 implies that surface $\mathrm{NO}_{x}$ sources contribute less than $20 \%$ to the upper tropospheric $(7-12 \mathrm{~km}) \mathrm{NO}_{x}$ burden, while the remaining $80 \%$ or so is added from its free-tropospheric sources. This result is not altered when model-calculated values of $\mathrm{NO}_{x}$ are used, as has been shown by Davis et al. [this issue]. The presence of freshly impacted air masses in the upper troposphere implies efficient convective transport. It is probable that processes of convection coexist with lightning which provides an important source of free-tropospheric $\mathrm{NO}_{x}$. Satellite images showed considerable deep convection over the western Pacific during the period of this experiment [Bachmeier et al., this issue]. Onboard storm scope indicated strong lightning activity in the area. $\mathrm{NO}_{y} / \mathrm{HC}$ ratios also increased with altitude although to a lesser degree than $\mathrm{NO}_{x}$. The $\mathrm{NO}_{y} / \mathrm{HC}$ ratio cannot be easily interpreted as the lifetime of $\mathrm{NO}_{y}$ cannot be accurately defined.

It has been proposed that reservoir species such as PAN are 


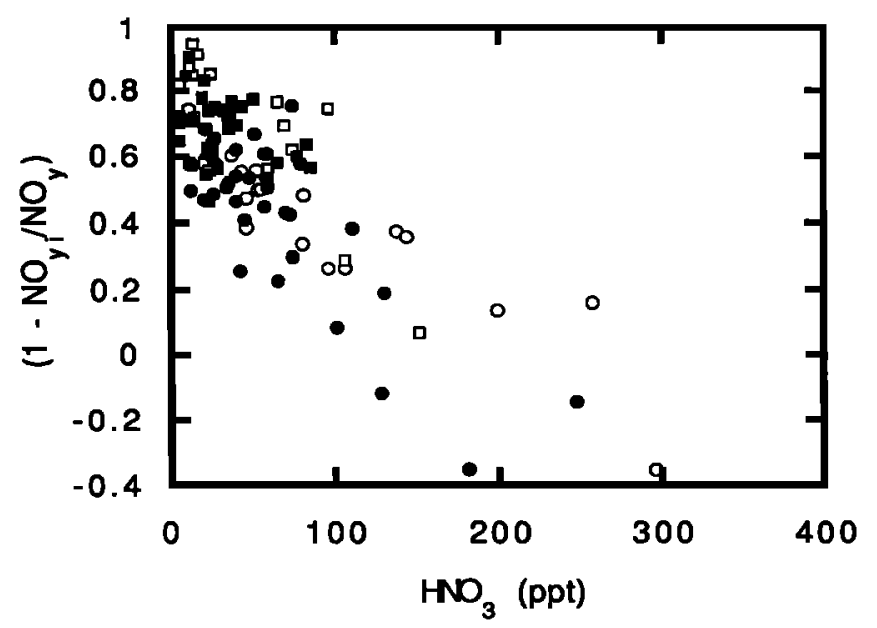

Figure 12. Relationship between reactive nitrogen shortfall and measured $\mathrm{HNO}_{3}$, as in Figure 11.

a major source of $\mathrm{NO}_{x}$ in remote atmospheres [Singh and Hanst, 1981; Jacob et al., 1992; Singh et al., 1992]. This appeared to be the case in the arctic/subarctic regions where high PAN and $\mathrm{NO}_{y}$ values were observed. Over the western Pacific, substantial concentrations of $\mathrm{NO}_{x}$ were present in the absence of large amounts of PAN. Figure 9 shows a plot of the $\mathrm{NO}_{x} /$ $\mathrm{NO}_{y}$ ratio as measured over the western Pacific as a function of the corresponding $\mathrm{C}_{2} \mathrm{H}_{2} / \mathrm{CO}$ ratio. It is evident from Figure 9 that the mean $\mathrm{NO}_{x} / \mathrm{NO}_{y}$ ratio lies between 0.1 to 0.2 and is relatively independent of altitude as well as the air mass age. A likely explanation for this is that the $\mathrm{NO}_{y}$ reservoir exerts a strong influence on $\mathrm{NO}_{x}$ and a $\mathrm{NO}_{y} \leftrightarrow \mathrm{NO}_{x}$ equilibrium may be present. Both $\mathrm{HNO}_{3}$ and $\mathrm{PAN}$ are known to exert such influences, but here we propose that the remainder of the reactive nitrogen reservoir, made up of largely unknown species, may also be helping to sustain the tropospheric abundance of $\mathrm{NO}_{x}$. Using a box model, Davis et al. [this issue] calculate that measured PAN and $\mathrm{HNO}_{3}$ could account for about $20 \%$ of the observed $\mathrm{NO}_{x}$ in the lowest troposphere steadily falling to about $5 \%$ in the upper troposphere. However, as has been discussed in detail in the next section, some $40-70 \%$ of $\mathrm{NO}_{y}$ is made up of unknown species. If these species behaved in a manner similar to $\mathrm{HNO}_{3}$, then some $50-100 \%$ of the $\mathrm{NO}_{x}$ could be due to recycling from the $\mathrm{NO}_{y}$ reservoir. Assuming all $\mathrm{NO}_{y}$ to be $\mathrm{HNO}_{3}$, an equilibrium $\mathrm{NO}_{x} /$ $\mathrm{NO}_{y}$ ratio of about $0.1-0.2$ can be calculated for the upper troposphere, although this ratio would be less than 0.1 in the lower troposphere. The nature of $\mathrm{NO}_{y}$, and therefore its contribution to $\mathrm{NO}_{x}$, remains a matter of both uncertainity and speculation.

Additional insights into sources are possible from model simulations as well. Model sensitivity runs were made with and without the lightning source as it appeared to be a large but uncertain source of reactive nitrogen in the free troposphere. In the western Pacific at $35^{\circ} \mathrm{N}$ in October, lightning contributed about 100-200 ppt $\mathrm{NO}_{y}$ in the upper troposphere (UT) (400$300 \mathrm{mbar}$ ), $40 \mathrm{ppt}$ in the middle troposphere (MT) (500 mbar), and 5-10 ppt in the lower troposphere (LT) (800 mbar). The corresponding $\mathrm{NO}_{y}$ mixing ratios at $15^{\circ} \mathrm{N}$ were $30-70 \mathrm{ppt}, 12$ ppt, and $5 \mathrm{ppt}$, respectively. Results from the study by Kasibhatla et al. [1991] show that in October, stratosphere contributed about 50-100 ppt (UT), 30 ppt (MT), and 5 ppt (LT) $\mathrm{NO}_{y}$ at $35^{\circ} \mathrm{N}$ and $15-20 \mathrm{ppt}$ (UT), $10 \mathrm{ppt}(\mathrm{MT})$, and $2 \mathrm{ppt}$ (LT) $\mathrm{NO}_{y}$ at $15^{\circ} \mathrm{N}$. Together, lightning and stratosphere could contribute about $150-300 \mathrm{ppt} \mathrm{NO}_{y}$ in the upper troposphere and 10-15 ppt $\mathrm{NO}_{y}$ in the lower troposphere at $35^{\circ} \mathrm{N}$. In the upper troposphere, $30-50 \%$ of the $\mathrm{NO}_{y}$ could be accounted for from these two natural sources. However, in the middle and lower troposphere, where a bulk of the reactive nitrogen mass resides, these contributions are much smaller. Overall model results suggest that in the $\mathrm{NH}$, some $60-70 \%$ of the $\mathrm{NO}_{y}$ reservoir can be attributed to surface emissions from anthropogenic and biogenic sources. Although MOGUNTIA did not include an explicit source due to aircraft emissions, this contribution to $\mathrm{NO}_{y}$ is expected to be small and well within other uncertainties. The suggestion by Liu et al. [this issue] that a major $\mathrm{NO}_{y}$ source due to aircraft emissions was present is most likely a consequence of their acknowledged underestimation of vertical convection in the region.

The MOGUNTIA model also showed that in the upper troposphere of the western Pacific, lightning contributed about $15 \mathrm{ppt} \mathrm{NO}_{x}$ at $35^{\circ} \mathrm{N}$ and some 8 ppt $\mathrm{NO}_{x}$ at $15^{\circ} \mathrm{N}$. Here lightning and the stratosphere together contributed about 40 ppt $\mathrm{NO}_{x}$ at $35^{\circ} \mathrm{N}$ and 20 ppt $\mathrm{NO}_{x}$ at $15^{\circ} \mathrm{N}$. The remainder is contributed by the $\mathrm{NO}_{y}$ reservoir species (such as PAN, organic nitrates, and $\mathrm{HNO}_{3}$ ). Addition of $\mathrm{HO}_{2} \mathrm{NO}_{2}(\approx 25 \mathrm{ppt}$ at $11 \mathrm{~km}$ ), a possible interferent in $\mathrm{NO}_{x}$ measurements, helps to improve the agreement between model predictions and measurements. Thus it appears that surface-based anthropogenic emissions contribute predominately to the global $\mathrm{NO}_{y}$ reservoir. Lightning, release of $\mathrm{NO}_{x}$ from the $\mathrm{NO}_{y}$ reservoir, and some direct transport from the surface collectively help to maintain the $\mathrm{NO}_{x}$ balance in the atmosphere. As stated earlier, subsonic aircraft release small but important quantities of $\mathrm{NO}_{x}$ $(0.7 \pm 0.4 \mathrm{Tg}(\mathrm{N}) / \mathrm{yr})$ at high altitudes, where it can have a long lifetime (5-7 days). It has been claimed that at high latitudes as much as $30 \%$ of upper tropospheric $\mathrm{NO}_{x}$ may be contributed by this source [Ehhalt et al., 1992]. No direct evidence of subsonic aircraft impact could be confirmed from these measurements. It is emphasized that accurate knowledge

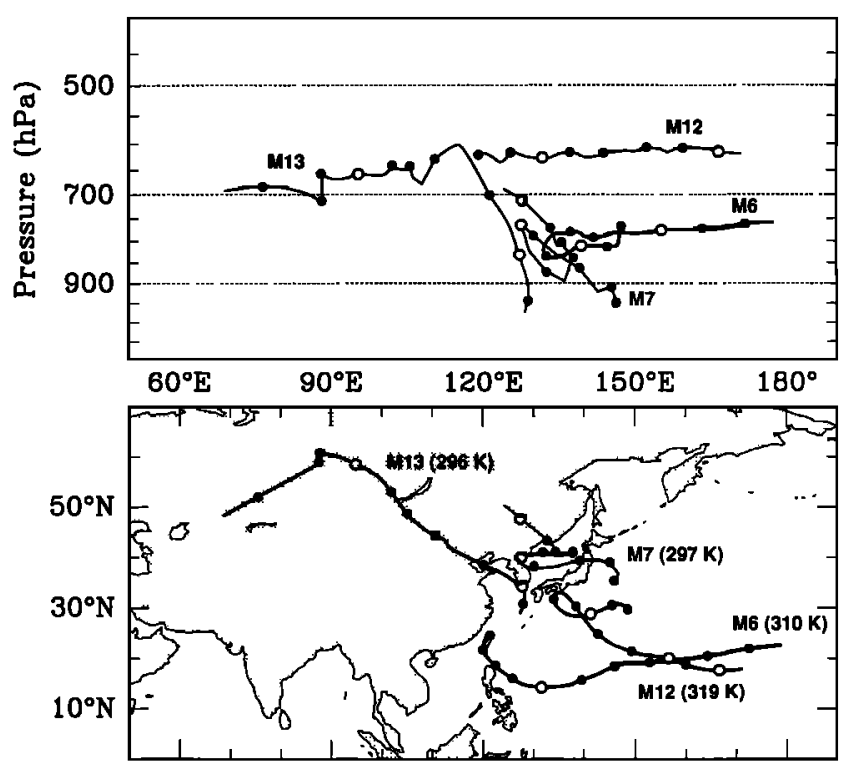

Figure 13. Example 10-day back trajectories showing possible continental (missions 7 and 13) and marine (missions 6 and 12) influences. 

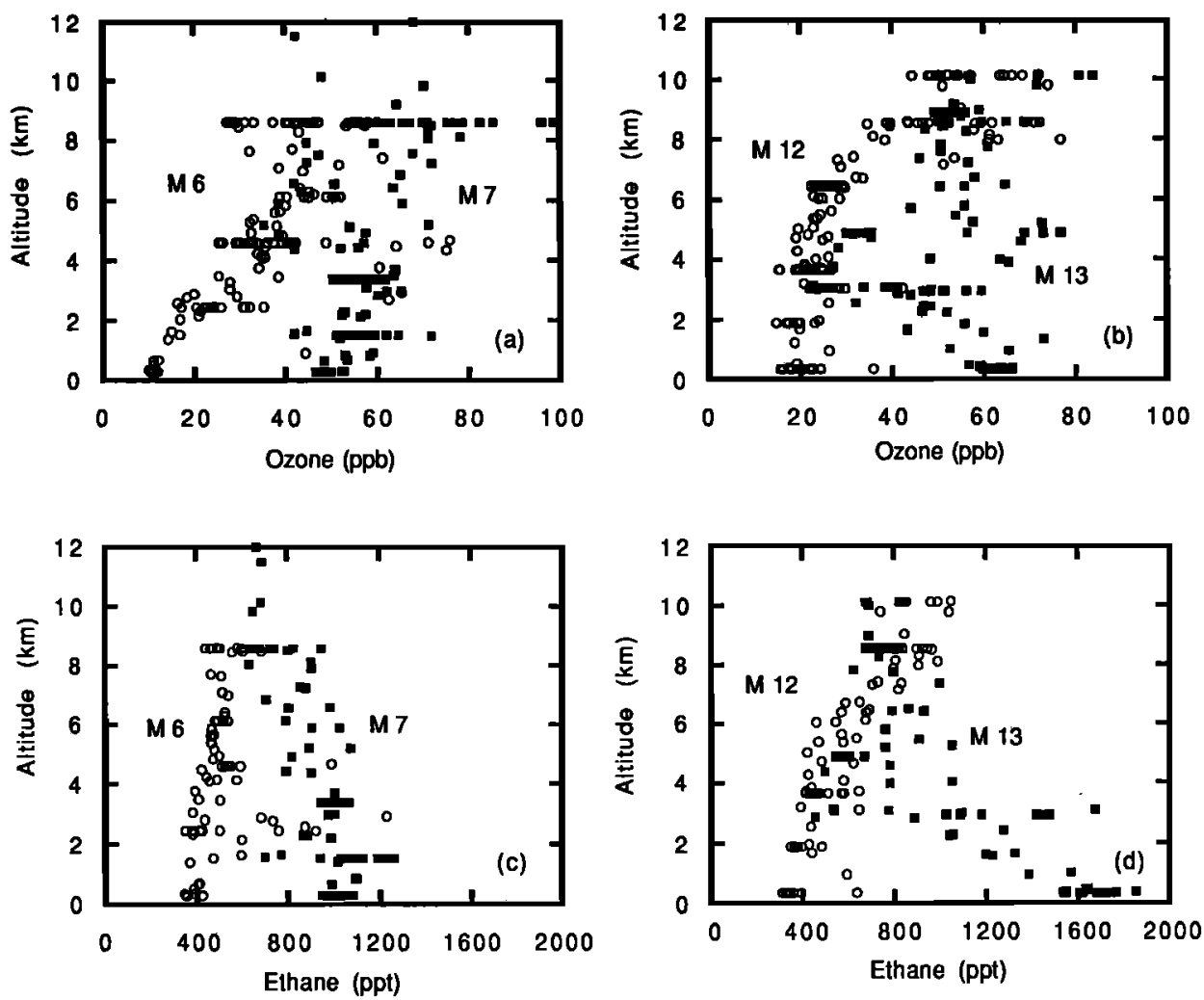

Figure 14. A comparison of the mixing ratios of $\mathrm{O}_{3}$ and $\mathrm{C}_{2} \mathrm{H}_{6}$ during marine (missions 6 and 12, circles) and continental outflow (missions 7 and 13, squares) conditions.

of the lightning source and its distribution is a major source of uncertainty in the budget of $\mathrm{NO}_{y}$ and $\mathrm{NO}_{x}$.

\section{Partitioning and Budget of Reactive Nitrogen}

Table 4 provides the fractional partitioning of each of the key species relative to $\mathrm{NO}_{y}$, along with the fraction of reactive nitrogen accounted and missing (mean, $\sigma$, median, and $\mathrm{N}$ ) for four altitude bands and two latitude bands. The $0-1 \mathrm{~km}$ altitude is included specifically for the boundary layer air. The

Table 5. Median Concentrations (0-4 km) During Conditions of Little and Substantial Continental Outflow

\begin{tabular}{|c|c|c|c|c|c|c|}
\hline \multirow[b]{2}{*}{ Compound } & \multicolumn{2}{|c|}{ Mission } & \multirow[b]{2}{*}{$\Delta^{*}$} & \multicolumn{2}{|c|}{ Mission } & \multirow[b]{2}{*}{$\Delta$} \\
\hline & 6 & 7 & & 12 & 13 & \\
\hline $\mathrm{O}_{3}, \mathrm{ppb}$ & 20 & 53 & 33 & 21 & 52 & 31 \\
\hline PAN, ppt & 2 & 141 & 139 & 2 & 120 & 118 \\
\hline $\mathrm{NO}_{y}, \mathrm{ppt}$ & 204 & 502 & 298 & 258 & 660 & 402 \\
\hline $\mathrm{NO}_{x}, \mathrm{ppt}$ & 42 & 85 & 43 & 30 & 70 & 40 \\
\hline $\mathrm{C}_{2} \mathrm{H}_{6}, \mathrm{ppt}$ & 410 & 1014 & 604 & 413 & 1417 & 1004 \\
\hline $\mathrm{C}_{3} \mathrm{H}_{8}, \mathrm{ppt}$ & 15 & 108 & 153 & 21 & 283 & 262 \\
\hline $\mathrm{CO}, \mathrm{ppb}$ & 69 & 109 & 40 & 72 & 128 & 56 \\
\hline $\mathrm{SO}_{2}, \mathrm{ppt}$ & 50 & 162 & 112 & 44 & 121 & 77 \\
\hline $\mathrm{SO}_{4}^{--}, \mathrm{ppt}$ & 66 & 123 & 57 & 283 & 940 & 657 \\
\hline $\mathrm{NO}_{3}^{-}, \mathrm{ppt}$ & 13 & 67 & 54 & 73 & 161 & 88 \\
\hline $\mathrm{C}_{2} \mathrm{Cl}_{4}, \mathrm{ppt}$ & 4 & 7 & 3 & 3 & 6 & 3 \\
\hline $\mathrm{H}_{2} \mathrm{O}_{2}$, ppt & 1526 & 1304 & -222 & 1770 & 2209 & -439 \\
\hline $\mathrm{CH}_{3} \mathrm{OOH}, \mathrm{ppt}$ & 1452 & 582 & -870 & 844 & 761 & -83 \\
\hline & & & $2.1-2.7$ & & & $0.5-0.7$ \\
\hline
\end{tabular}

${ }^{*} \Delta$ is the difference between the median mixing ratios.

$\dagger R=\left(\Delta \mathrm{NO}_{y}+\Delta \mathrm{NO}_{3}^{-}\right) /\left(\Delta \mathrm{SO}_{2}+\Delta \mathrm{SO}_{4}^{-}\right)$. The range in $R$ is due to the interpretation of sparse $\mathrm{SO}_{4}^{--}$and $\mathrm{NO}_{3}^{-}$aerosol measurements. quantity $\mathrm{NO}_{y}$ is defined as the sum of the observed gaseous odd nitrogen species $\left(\mathrm{NO}_{y_{z}}=\mathrm{NO}+\mathrm{NO}_{2}+\mathrm{PAN}+\mathrm{PPN}+\right.$ $\mathrm{HNO}_{3}$ ). PPN was present in extremely small and often undetectable concentrations $(<2 \mathrm{ppt})$. Although aerosol nitrates were present $\left(\approx 10 \%\right.$ of $\left.\mathrm{NO}_{y}\right)$, only the fine aerosol fraction would have some chance of being sampled by the aircraft $\mathrm{NO}_{y}$ instrument. No size-fractionated aerosol measurements were done, but previous studies from remote clean air have shown that a substantial fraction of nitrate aerosols are generally found in the coarse fraction (e.g., crustal materials). Hence aerosol $\mathrm{NO}_{3}$ - is not included in the definition of $\mathrm{NO}_{y t}$. We note here that aerosol nitrate, as a fraction of $\mathrm{NO}_{y}$, was higher in the western Pacific compared to other pristine places such as the subarctic. To the extent that some aerosol nitrate may be sampled as $\mathrm{NO}_{y}$, a small error is possible. As has been discussed above, there were large differences in the $\mathrm{NO}_{y}$ measurements of GIT and NU even at high altitudes (above $7 \mathrm{~km}$ ), where moisture-related interference is negligible. To illustrate the nature of these differences, results from the $7-$ to $12-\mathrm{km}$ band are provided with both GIT and $\mathrm{NU} \mathrm{NO}_{y}$ data.

Table 4 shows that for $25^{\circ}-42^{\circ} \mathrm{N}$ and in the free troposphere the contribution of PAN and $\mathrm{NO}_{x}$ to $\mathrm{NO}_{y}$ is about equal. This is a major departure from the eastern Pacific where PAN concentrations were typically 4-5 times $\mathrm{NO}_{x}$ [Ridley et al., 1990]. Similarly, $\mathrm{HNO}_{3}$ constituted a large fraction $(\approx 40 \%)$ of $\mathrm{NO}_{y}$ in the boundary layer declining to extremely low values $(\approx 7 \%)$ in the upper troposphere. The fractional presence of individually measured species was significantly lower in the tropical/equatorial latitudes $\left(0^{\circ}-25^{\circ} \mathrm{N}\right)$. In the middle troposphere (3-7 km), PAN, $\mathrm{NO}_{x}$ and, $\mathrm{HNO}_{3}$ were each about $10 \%$ of the measured $\mathrm{NO}_{y}$. As expected, PAN was a minor contrib- 

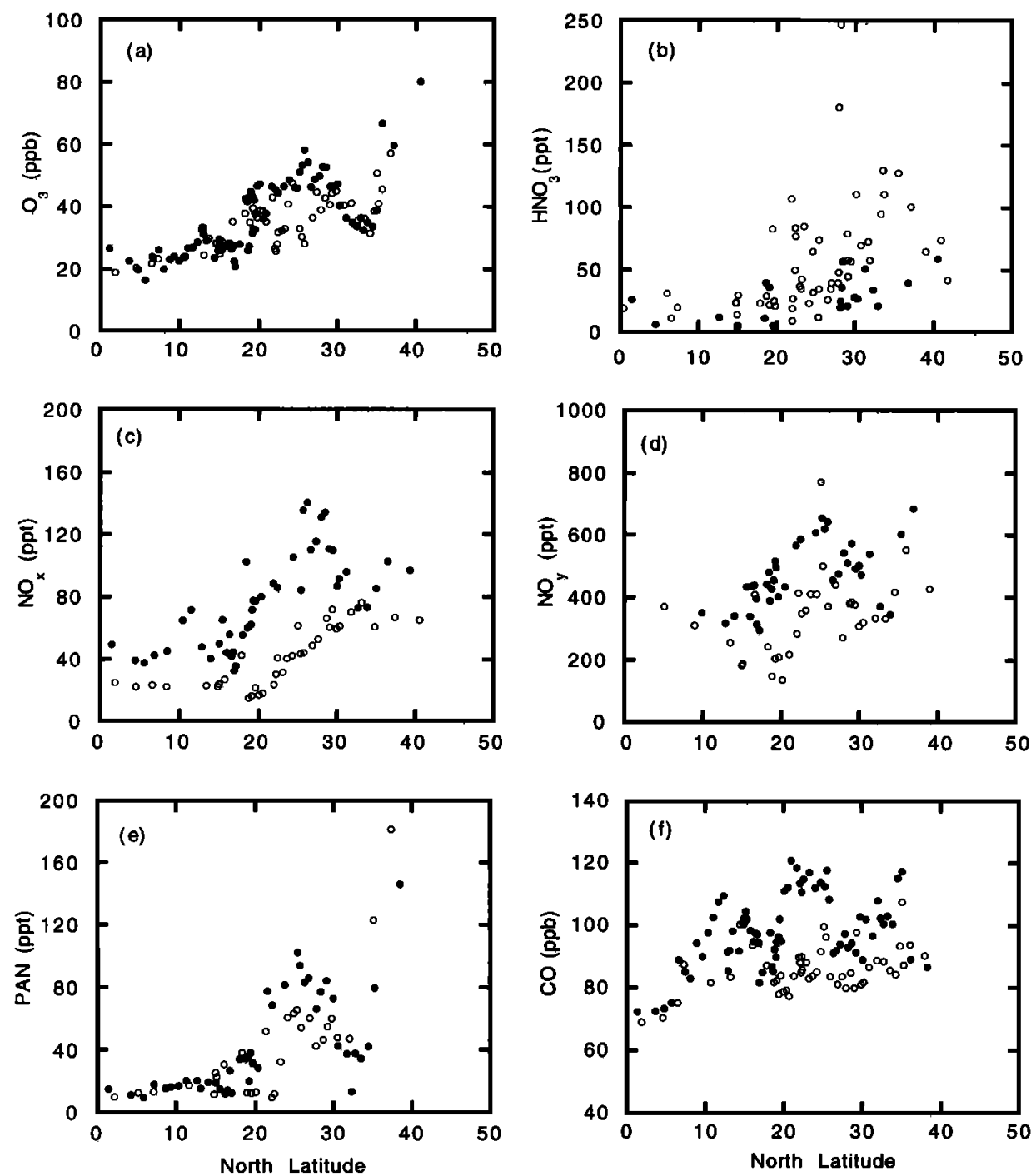

Figure 15. Latitudinal distribution of $\mathrm{O}_{3}$, select reactive nitrogen $\left(\mathrm{NO}_{x}, \mathrm{PAN}, \mathrm{HNO}_{3}\right.$, and $\left.\mathrm{NO}_{y}\right)$ and tracer (CO) species over the western Pacific; 3-7 km (open circles), 7-12 km (solid circles). Each symbol is an average of 10 data points.

utor to the $\mathrm{NO}_{y}$ budget in the boundary layer because of its short lifetime there. Similarly, $\mathrm{HNO}_{3}$ was relatively more important in the boundary layer where it can be both easily synthesized from rapid $\mathrm{NO}_{x}$ oxidation and destroyed by surface deposition.

Figure 10 shows a plot of the mean fractional contribution of each of the species to the total nitrogen budget for the two selected latitude bands. It is evident from Figure 10 (also Table 4) that about $60 \%$ of the reactive nitrogen could be accounted for (40\% shortfall) for midlatitude/subtropical latitudes and only $30 \%$ ( $70 \%$ shortfall) for tropical/equatorial latitudes. This shortfall is substantially larger than that noted from the ground sites in the Pacific as well as from other regions of the troposphere [Fahey et al., 1986; Ridley, 1991; Atlas et al., 1992; Sandholm et al., 1992, 1994; Singh et al., 1992, 1994]. The situation is a bit more reasonable when the $\mathrm{NU} \mathrm{NO}_{y}$ data are used (only $7-12 \mathrm{~km}$ ) resulting in mean shortfalls of 30 and $40 \%$ for the two latitude bands. This amounts to some $300 \mathrm{ppt}$ versus 100 ppt of missing reactive nitrogen for 7-12 km. Clearly, instrumental errors are a major source of uncertainity in defining and understanding this shortfall. Figure 11 shows the relationship of $\mathrm{NO}_{y}$ with that of $\mathrm{NO}_{y}$ and $\mathrm{O}_{3}$. As expected, $\mathrm{NO}_{y}$ is nearly always higher than $\mathrm{NO}_{y l}$ and a linear relation with $\mathrm{O}_{3}$ is present. We studied the relationship of the reactive nitrogen shortfall with that of other species such as ozone, reactive nitrogen species, tracers, and parameters that might indicate the air mass age $\left(\mathrm{C}_{2} \mathrm{H}_{2} / \mathrm{CO}\right.$ ratio). High shortfalls could be seen both under conditions of low and high $\mathrm{C}_{2} \mathrm{H}_{2} / \mathrm{CO}$ ratios. Generally, no special relationships were evident except in the case of $\mathrm{HNO}_{3}$. Figure 12 shows a plot of the reactive nitrogen shortfall as a function of $\mathrm{HNO}_{3}$ and an inverse relationship is present; that is, the shortfall is modest when $\mathrm{HNO}_{3}$ concentrations are $100 \mathrm{ppt}$ or larger and increases with decreasing $\mathrm{HNO}_{3}$ concentrations. This inverse relationship between nitrogen shortfall and $\mathrm{HNO}_{3}$ abundance is contrary to the linear relationship observed by Atlas et al. [1992]. These measurements strongly indicate that a dominant fraction of the global nitrogen is made up of hitherto unknown species, especially in the tropics. The possibility cannot be ruled out that at least in some cases, measurement difficulties may also be present. 


\section{Impact of Continental Outflow on Western Pacific}

Figure 13 shows example trajectories from four missions which were alternately minimally or strongly impacted by continental emissions. Trajectory analysis indicated that missions 7 and 13 provide instances where continental outflow from Japan or China may have occurred, while missions 6 and 12 were relatively unimpacted by Asian emissions. The vertical distribution of $\mathrm{O}_{3}$ and $\mathrm{C}_{2} \mathrm{H}_{6}$ during missions 6 and 7 and 12 and 13 is shown in Figure 14 and the continental impact is evident from the enhanced mixing ratios. Table 5 summarizes the median concentrations of a large number of species for the $0-4$ $\mathrm{km}$ altitude for these missions. In general, the differential $(\Delta)$ due to Japan outflow (mission 7) is very similar to that from China outflow (mission 13). For example, in both instances a $\Delta$ of some 30-35 ppb $\mathrm{O}_{3}, 120-140 \mathrm{ppt}$ PAN, and 300-400 ppt $\mathrm{NO}_{y}$ was observed. This $\Delta \mathrm{O}_{3} / \Delta \mathrm{NO}_{y}$ of about 100 is an order of magnitude higher than what was encountered over North America [Olszyna et al., 1994]. The large $\Delta \mathrm{O}_{3} / \Delta \mathrm{NO}_{y}$ is indicative of the very high efficiency with which $\mathrm{O}_{3}$ is produced over the Pacific, when compared to typical rural sites over North America. Emission inventories compiled for Asia [Kato and Akimoto, 1992] suggest that the nitrogen to sulfur ratio (vol/ vol) is about 2.5 for Japan and 0.5 for China. This ratio is calculated as $R$ in Table 5. Indeed $R$ is much higher for the Japanese-influenced air $(R=2.1-2.7)$ compared to the Chinese-influenced air $(R=0.5-0.7)$. The bulk of the extra sulfur from China appears to be in the form of sulfate aerosols. It is perhaps important to note that in the case of peroxides the reverse was found to be true and the mixing ratios were lower in the air impacted by continental emissions. This is expected since continental outflow often involves convective processes during which peroxides could be scavenged.

Figure 15 shows the latitudinal profile for key species measured in the western Pacific free troposphere (3-7 km, 7-12 $\mathrm{km}$ ) during PEM-West $A$. In virtually all cases a north/south gradient is evident. Elevated $\mathrm{O}_{3}$, precursor and tracer concentrations are nearly always encountered between $20^{\circ}$ and $30^{\circ} \mathrm{N}$ latitude where a great deal of the Asian continental outflow occurs. The impact of this outflow is greater at high altitudes. This is evident from the distribution of $\mathrm{C}_{2} \mathrm{H}_{2}$ (Figure 15f) which is a relatively inert hydrocarbon tracer. These data clearly show that convective processes are at work and pollutants are carried aloft relatively rapidly and then transported via fast winds in the upper troposphere. Species such as $\mathrm{HNO}_{3}$, which are easily scavenged during convective processes, do not show such behavior (Figure 15b). The vertically increasing concentrations of hydrocarbons [Blake et al., this issue] and $\mathrm{CO}$ (e.g., Figure 3e) are in large part a result of this upper tropospheric transport phenomenon. In remote marine atmospheres the upper troposphere in many ways acts as a source for pollutants to the boundary layer. Detailed statistics and modeling results on the impact of continental outflow can be found in the works of Liu et al. [this issue] and Talbot et al. [this issue].

\section{Conclusions}

The distribution of reactive nitrogen and ozone has been studied in the atmosphere over the western Pacific Ocean. Observations are in general accord with model results, but there appear to be important disagreements in some cases (e.g., $\mathrm{HNO}_{3}$ ). The reservoir of atmospheric $\mathrm{NO}_{y}$ is strongly influenced by anthropogenic sources. This $\mathrm{NO}_{y}$ reservoir is probably an indirect source of atmospheric $\mathrm{NO}_{x}$ at all alti- tudes. It is inferred that surface sources of $\mathrm{NO}_{x}$ only minimally impact its upper tropospheric abundance in a direct way and here nonsurface sources dominate. These may include lightning, stratospheric injections, aircraft emissions, and rapid conversion of $\mathrm{NO}_{y}$ to $\mathrm{NO}_{x}$ via as yet unknown mechanisms. The budget of reactive nitrogen is poorly accounted for and if these measurements are accurate, large quantities of reactive nitrogen present in the atmosphere are made up of hitherto unknown species. During conditions involving westerly flow, the western Pacific is strongly impacted by Asian continental sources at all altitudes. The continental impact at the upper tropospheric levels is the strongest, but the sources are probably global and not limited to the Asian continent. Trajectory analysis and a comparison of measurements with source inventories can be used to identify recent source regions. The impacted air masses are highly efficient in ozone formation. Sources of atmospheric reactive nitrogen cannot yet be accurately defined due to shortcomings in measurements and theory.

Acknowledgments. This research was supported by the NASA Global Tropospheric Experiment. We acknowledge all PEM-West A participants for their cooperation and support. Special thanks are due to the flight and ground crew of the NASA Ames Research Center for making this effort a success. We are grateful to W. Viezee of SRI International, E. Shadd, and H. Lee of Synernet for meteorological and computational support. Constructive discussions with D. Jacob of Harvard University and R. Chatfield of NASA Ames are much appreclated.

\section{References}

Atlas, E., et al., Partıtioning and budget of $\mathrm{NO}_{y}$ species during midlatitude MLOPEX, J. Geophys. Res., 97, 10,449-10,462, 1992.

Bachmeier, A. S., R. E. Newell, M. C. Shipham, Y. Zhu, D. R. Blake, and E. V. Browell, PEM-West A: Meteorological overview, J. Geophys. Res, this issue.

Blake, D. R., T.-Y. Chen, T. W. Smith Jr., C. J.-L. Wang, O. W. Wingenter, N. J. Blake, F. S. Rowland, and E. W. Mayer, Threedimensional distribution of nonmethane hydrocarbons and halocarbons over the northwestern Pacific during the 1991 PEM-West A, $J$. Geophys. Res, this issue.

Carroll, B. A., et al., Aircraft measurements over the eastern Pacific Ocean and contınental United States and implications for ozone production, J. Geophys. Res., 95, 10,205-10,233, 1990.

Chatfield, R. B., Anomalous $\mathrm{HNO}_{3} / \mathrm{NO}_{x}$ ratio of remote tropospheric air: Is there conversion of nitric acid to formic acid and $\mathrm{NO}_{x}$, Geophys. Res. Lett, 8, 2705-2708, 1994.

Crawford, J. D., et al., Photostationary state analysis of the $\mathrm{NO}_{2}-\mathrm{NO}$ system based on airborne observations over western and central North Pacific Ocean, J. Geophys. Res, this issue.

Crosley, D., The 1993 NASA blue ribbon $\mathrm{NO}_{y}$ panel report, $M P$ 93-185, SRI Int., Menlo Park, Calif., 1993.

Crutzen, P. J., and P. H. Zimmermann, The changing photochemistry of the troposphere, Tellus, 43(AB), 136-151, 1991.

Davis, D. D., et al., Assessment of ozone photochemistry in the western North Pacific as inferred from PEM-West A observations during fall 1991, J. Geophys. Res, this issue.

Dibb, J. E., W. Talbot, K. I. Klemm, G. L. Gregory, H. B. Singh, J. D. Bradshaw, and S. T. Sandholm, Asian influence over the western North Pacific during the fall season: Inferences from lead 210, soluble ionic species, and ozone, $J$. Geophys. Res, this issue.

Dentener, F. J., and P. J. Crutzen, Reaction of $\mathrm{N}_{2} \mathrm{O}_{5}$ on tropospheric aerosols: Impact on the global distributions of $\mathrm{NO}_{k}, \mathrm{O}_{3}$, and $\mathrm{OH}$., $J$. Geophys. Res., 98, 7149-7163, 1993.

Ehhalt, D., et al., Sources and distribution of $\mathrm{NO}_{x}$ in the upper troposphere at northern midlatitudes, J. Geophys. Res., 97, 3725-3738, 1992.

Fan, S.-M., et al., The origin of tropospheric $\mathrm{NO}_{x}$ over subarctic eastern Canada in summer, J. Geophys. Res, 99, 16,867-16,877, 1994. Fahey, D. W., et al., Reactive nitrogen species in the troposphere: 
Measurements of $\mathrm{NO}, \mathrm{NO}_{2}, \mathrm{HNO}_{3}$, particulate nitrate, peroxyacetyl nitrate (PAN), $\mathrm{O}_{3}$, and total reactive odd nitrogen $\left(\mathrm{NO}_{y}\right)$ at Niwot Ridge, Colorado, J. Geophys. Res., 91, 9781-9793, 1986.

Feichter, J., and P. J. Crutzen, Parameterization of the vertical tracer transport due to deep cumulus convection in a global transport model and its evaluation with 222 Radon measurements, Tellus, 42(B), 100-117, 1990.

Hoell, J. M., D. D. Davis, S. C. Liu, R. Newell, M. Shipham, H. Akimoto, R. J. McNeal, R. J. Bendura, and J. Drewry, Pacific Exploratory Mission-West A (PEM-West A): September-October, 1991, J. Geophys. Res, this issue.

Huebert, B. J., et al., Measurements of nitric acid and $\mathrm{NO}_{x}$ ratios in the troposphere, J. Geophys. Res., 95, 10,193-10,198, 1990.

Jacob, D. J., et al., Summertime photochemistry of the troposphere at high northern latitudes $J$. Geophys. Res., 97, 16,421-16,431, 1992.

Kanakidou, M., H. B. Singh, K. M. Valentin, and P. J. Crutzen, A two-dimensional model study of ethane and propane oxidation in the troposphere, J. Geophys. Res., 96, 15,395-15,413, 1991.

Kanakidou, M., P. J. Crutzen, P. H. Zimmermann, and B. Bonsang, A 3 dimensional global study of the photochemistry of ethane and propane in the troposphere: Production and transport of organic nitrogen compounds, in Air Pollution Modeling and Its application $L X$, edited by H. van Dop, and G. Kallos, pp. 415-426, Plenum, New York, 1992.

Kasibhatla, P. S., H. Levy II, W. J. Moxim, and W. L. Chameides, The relative impact of stratospheric photochemical production on tropospheric $\mathrm{NO}_{y}$ levels: A model study, J. Geophys. Res., 96, 18,631$18,646,1991$.

Kato, N., and H. Akimoto, Anthropogenic emissions of $\mathrm{SO}_{2}$ and $\mathrm{NO}_{x}$ in Asia: Emission inventories, Atmos. Environ., (26)A, 2997-3017, 1992.

Koike, M., Y. Kondo, S. Kawakami, H. B. Singh, H. Ziereis, and J. T. Merrill, Ratios of reactive nitrogen species over the Pacific during PEM-West A, J. Geophys. Res., this issue.

Kondo, Y., H. Ziereis, M. Koike, S. Kawakami, G. L. Gregory, G. W. Sachse, H. B. Singh, D. D. Davis, and J. T. Merrill, Reactive nitrogen over the Pacific Ocean during PEM-West A, J. Geophys. Res., this issue.

Langner, J., and $\mathrm{H}$. Rodhe, A global three-dimensional model of the tropospheric sulfur cycle, J. Atmos. Chem., 13, 225-265, 1991.

Liu, S. C., et al., A model study of trace species distributions during PEM-West A, J. Geophys. Res., this issue.

McNeal, R. J., J. P. Mugler Jr., R. C. Harriss, and J. M. Hoell Jr., NASA Global Tropospheric Experiment, Eos Trans. $A G U, 64,561-$ 562,1983

Merrill, J. T., Trajectory results and interpretation for PEM-West A, $J$. Geophys. Res., this issue.

Murphy, D. M., et al., Reactive nitrogen and its correlation with ozone in the lower stratosphere and upper troposphere, J. Geophys. Res., $98,8751-8773,1993$.

Norton, E., et al., Measurements of nitric acid and aerosol nitrate at the Mauna Loa Observatory during MLOPEX 1988, J. Geophys. Res., 97, 10,415-10,425, 1992.

Olszyna, K., E. M. Bailey, R. Simonaitis, and J. F. Meagher, $\mathrm{O}_{3}$ and $\mathrm{NO}_{y}$ relationships at a rural site, J. Geophys. Res., 99, 14,557-14,563, 1994.

Prospero, J. M., and D. L. Savoi, Effects of continental sources of nitrate concentrations over the Pacific Ocean, Nafure, 33, 687-689, 1989.

Ridley, B. A. Recent measurements of oxidized nitrogen compounds in the troposphere, Atmos. Environ., 25(A), 1905-1926, 1991.

Ridley, B. A., et al., Ratio of PAN to active nitrogen observed during aircraft flights over the eastern Pacific Ocean and continental United States, J. Geophys. Res., 95, 10,179-10,192, 1990.

Sandholm, S., et al., Arctic tropospheric observations related to $\mathrm{N}_{x} \mathrm{O}_{y}$ distributions: ABLE 3A, J. Geophys. Res., 97, 16,481-16,510, 1992.

Sandholm, S., et al., Summertime partitioning and budget of $\mathrm{NO}_{y}$ compounds in the troposphere over Alaska and Canada: ABLE 3, J. Geophys. Res., 99, 1837-1861, 1994.

Singh, H. B., and P. L. Hanst, Peroxyacetyl nitrate (PAN) in the unpolluted atmosphere: An important reservair for nitrogen oxides, Geophys Res. Lett., 8, 941-944, 1981.

Singh, H. B., and P. Zimmerman, Atmospheric distributions and sources of nonmethane hydrocarbons, Adv. Environ. Sci. Technol., 24, 177-235, 1992.

Singh, H. B., et al., PAN measurements during CITE 2: Atmospheric distribution and precursor relationships, J. Geophys. Res., 95, 10,163-10,178, 1990.

Singh, H. B., et al., Relationship of PAN to active and total odd nitrogen at northern high latitudes: Influence of reservoir species on $\mathrm{NO}_{x}$ and $\mathrm{O}_{3}, J$. Geophys. Res., 97, 16,523-16,531, 1992.

Singh, H. B., et al., Summertime distribution of peroxyacetyl nitrate and other reactive nitrogen species in the northern high-latitude atmosphere of eastern Canada, J. Geophys. Res., 99, 1821-1835, 1994.

Smyth, S., et al., Comparison of free tropospheric western Pacific air mass classification schemes for the PEM-West A experiment, $J$. Geophys. Res, this issue.

Talbot, R. W., A. S. Vijgen, and R. C. Harriss, Measuring tropospheric $\mathrm{HNO}_{3}$ : Problems and prospects for nylon filter and mist chamber techniques, J. Geophys. Res., 95, 7553-7561, 1990.

Talbot, R. W., et al., Chemical characteristics of continental outflow from Asia to the troposphere over the western Pacific Ocean during September-October 1991: Results from PEM-West A, J. Geophys. Res., this issue.

Travagli, G., L'etere dinitrico del metilenglicol, Gazz. Chim. Ital., 68, 718-721, 1938.

D. R. Blake and F. S. Rowland, University of California, Irvine, CA 92717.

J. D. Bradshaw, J. Crawford, D. D. Davis, and S. T. Sandholm, Georgia Institute of Technology, Atlanta, GA 30332.

E. Browell, G. L. Gregory, and G. W. Sachse, NASA Langley Research Center, Hampton, VA 23665.

J. Crutzen, Max Planck Institute for Chemistry, D 55020 Mainz, Germany.

B. Heikes and J. Merrill, University of Rhode Island, Narragansett, RI 02882.

D. Herlth, R. Kolyer, and H. B. Singh (corresponding author), NASA Ames Research Center, Code 245-5, Moffett Field, CA 940351000.

M. Kanakidou, Centre des Faibles Radioactivites, Laboratoire mixte CNRS/CEA, F-91198 Gif-sur-Yvette, France.

M. Koike and Y. Kondo, Nagoya University, Toyokawa, Japan.

S. C. Liu, NOAA Aeronomy Laboratory, Boulder, CO 80303.

R. Newell, MIT, Cambridge, MA 02139.

L. Salas, San Jose State University Foundation, Moffett Field, CA 94035.

R. Talbot, University of New Hampshire, Durham, NH 03824.

(Received July 6, 1994; revised February 20, 1995; accepted February 20, 1995.) 